\title{
Institute for Development
}

SKILLED-UNSKILLED WAGE

GAP VERSUS EVOLVING TRADE AND LABOUR MARKET

STRUCTURES IN THE EU

AleksandRa PARTEKa

Institute for Development

Working Papers no. 004/2012 


\title{
Instytut Rozwoju \\ Institute for Development Working Papers \\ Working Paper no. 004/2012 (008) \\ ISSN 2082-7318
}

\section{Editorial Committee:}

Jacek Szlachta

Krystyna Gawlikowska-Hueckel

\author{
Publisher: \\ Instytut Rozwoju \\ ul. A. Mickiewicza 10 \\ 81-832 Sopot, Poland \\ e-mail: office@instytut-rozwoju.org
}

\begin{abstract}
Working Papers are written by the Staff of the Institute for Development or by experts working in association with them. The views expressed in the Working Paper are the author's alone and do not necessarily correspond to those of the Institute for Development. Comments and enquiries should be addressed to:

Instytut Rozwoju

ul. A. Mickiewicza 10

81-832 Sopot, Poland

e-mail: office@instytut-rozwoju.org
\end{abstract}

This paper exists in English only and can be downloaded from the website www.instytut-rozwoju.org.

(C) Instytut Rozwoju, 2012 


\title{
SKILLED-UNSKILLED WAGE GAP VERSUS EVOLVING TRADE AND LABOUR MARKET STRUCTURES IN THE EU
}

\author{
Aleksandra Parteka ${ }^{1}$
}

\begin{abstract}
This paper proposes an alternative approach to the empirical study of wage gap between workers with different educational levels in the enlarged EU. The analysis is based on sectoral database, linking labor market statistics and trade data at the level of 12 manufacturing sectors in a group of 20 European countries: selected New Member States (NMS-5) and former EU-15 economies, in the period 1995-2005. The results of the empirical model suggest that wage inequality between workers with academic education and lower is associated mainly with domestic (and not foreign) labor market conditions and, to a lower extent, to trade forces. Degree of trade penetration affects skilledunskilled wage gaps but we do not find significant wage effects of imports from less developed EU countries. The same result is confirmed when we consider trade in intermediates and outsourcing practises in Europe.
\end{abstract}

JEL: C62, F16, J31

Keywords: wage inequality, skills, integration

\footnotetext{
${ }^{1}$ Gdansk University of Technology, Faculty of Management and Economics, Narutowicza 11/12, 80-233 Gdansk, Poland; e-mail: aparteka@,zie.pg.gda.pl. The author gratefully acknowledges financial support from CERGE-EI (10th GDN RRC grant). I am grateful for valuable comments and suggestions from Prof. Randy Filer, as well as the participants of: CERGE-EI XRRC Conference (Prague, August 2010), ETSG conference (University of Lausanne, Switzerland, September 2010), Warsaw International Economic Meeting (University of Warsaw, Poland, June 2011) and research seminars in Yasar University (Izmir, Turkey, May 2010), Eotvos Lorand University (Budapest, Hungary, June 2010) and University of Ancona (Ancona, Italy, June 2011). Usual disclaimers apply.
} 


\section{Introduction}

The debate on the determinants of wage differentials between skilled and unskilled workers has been on the top of the research agenda since the appearance of the first studies addressing this issue, based on the experience of industrialised economies in the 1980s and 1990s. The original evidence presents rather mixed picture, depending on the approach followed. Making a basic distinction between trade and labor economics ${ }^{2}$, widening wage dispersion in some industrialised countries has been initially attributed to a shift in the demand towards more skilled labor, resulting from pressures from low income countries due to trade liberalisation (Leamer, 1992; Leamer, 1996; Wood, 1992; Wood, 1994; Wood, 1995; Burtless, 1995), more intensive trade and migration (Borjas et al., 1992), foreign outsourcing (Feenstra and Hanson, 1996; Feenstra and Hanson, 2001) or within the labor stream - from so called 'skill-biased technological change' (Autor et al. 1998; Berman et al., 1994; Katz and Murphy, 1992; Katz and Autor, 1999; di Nardo and Card, 2002, Autor et al., 2008).

Much less emphasis has been put on the analysis of wage inequality in least developed countries $(L D C)$ - the main problem which remains very difficult to overcome in the empirical analysis is the limited availability of the data allowing for longitudinal analysis, especially at the micro level. $^{3}$ The arguments justifying increasing wage inequality in $L D C$ - phenomenon at the first sight contrary to the neoclassical explanations - can be found in the approach relaxing some of the assumptions of H-O/St-Sam theory and considering 'cones of diversification' (Davis, 1996), suggesting that what really matters is the relative position of a given country within a group of similar, in terms of endowments and production structure, economies (called a 'cone'). Moreover, outward processing trade may result in changes in the division of skills across industries both in the home country and in a country where the production activity has been moved. As a result, evolving specialisation patterns demonstrated in the employment structures, as well as in the international trade, can provoke the increase of the wage gap between skilled and unskilled workers both in developed and developing economies. However, recent paradigms (Grossman and Rossi-Hansberg,

\footnotetext{
${ }^{2}$ Trade stream draws on the predictions of Hecksher-Ohlin (H-O) and Stolper-Samuelson (St-Sam) theorems: trade liberalization (as well as falling transport and communication costs) and the competition from the developing countries is seen as the main cause of the outward shift of the demand curve for skilled (relative to unskilled) labor force in the developed economies. Consequently, ceteris paribus, relative decline of unskilled workers' wages would imply widening wage inequality in the latter countries. Labor literature, instead, emphasizes the role played by the movement of technology frontier - in this context caused mainly the diffusion of computers in all spheres of economic (an non) activity.

${ }^{3}$ See: Attanasio et al. (2004) for evidence on Columbia; Chambargwala (2006) on India; Robertson (2004) on Mexico.
} 
2008) argue that low skilled labor needs not to be a looser from the globalisation as productivity gains can overcome the effects of labor substitution across countries.

In this context the enlarged European Union is an extremely interesting case study, as it encompasses economies at very different levels of economic development and wage levels. As a result of progressing deeper and wider integration, the countries involved have created a very particular setting with strong trade links and dynamically changing patterns of labor allocation. In the recent decade, major changes have been caused by the trade opening of the Western European countries towards the Central and East Europe (CEE), after the Europe Agreements in mid 1990s and the recent enlargements of the EU in 2004 and 2007. In particular, outward processing trade gained importance (Egger and Egger, 2005) as low demanding tasks were easily outsourced from EU-15 countries to the Central Europe (Baldone et al., 2001).

Distributional effects of these changes are of a great relevance in New Member States (NMS). These ex-communist ex-centrally planned economies while hidden behind the 'iron curtain ${ }^{\prime 4}$ were characterized by low income per capita levels but also by low levels of inequality within the society. Its increase is perceived to be one of the main costs of the transition (Heyns, 2005; Milanovic, 1998). On one hand great wage convergence towards the levels typical for Western European economies was expected, on the other hand, however, a common fear was that inequalities within transition economies would grow. Consequently, more and more attention has been drawn to the problems of the distributional consequences of transition and economic restructuring in Central and Eastern Europe. Quality upgrading has been registered in some NMS (Dulleck et al., 2005; Zaghini, 2005). The movement towards more skill intensive industries as a result of trade based linkages and technology transmission mechanisms (Keller, 2002) is likely to favour certain kind of sectors. It means that also in 'new' EU countries we could observe the widening of the gaps between wages according to the skill level required and resulting from the technological change (Bartel and Sicherman, 1999; Acemoglu, 2002).

Still, even though the process of economic transformation and restructuring, as well as trade reintegration with the Western Europe, have been widely studied (among others: Benedictis and Tajoli, 2007; Kaminski and Ng, 2005; Kornai, 2006; Landesmann, 2003), relatively little research has been done on wage inequality patterns in the enlarged Europe and in NMS in particular. ${ }^{5}$ The

\footnotetext{
${ }^{4}$ The expression was used by Winston Churchill during his speech at Westminster College in Fulton, Missouri on March the 5 th, 1946.

${ }^{5}$ In case of transition economies mainly the aspect of income distribution has been analyzed (Aghion and Commander,
} 
evidence confirms that overall earnings inequality rose in CEE countries in the years following the transition (Rutkowski, 1997) and the labor reallocation has played a role in this process (Boeri and Terrell, 2002). However, among studies dealing specifically with the determinants of rising wage inequality in the countries of our interest, we may find mainly analysis limited in the geographical cover to one or very few NMS (and Russia) - probably due to problems with restricted availability and comparability of the micro data. ${ }^{6}$ Also the evidence concerning former EU-15 economies is limited in country cover. Most studies have been focused on wage patterns in the UK (Green et al., 2003; Haskel and Slaughter, 2001; Machin, 1996; Wood, 1995), Germany (Welsch, 2004), Italy (Mannasse et al., 2004) or samples of few European countries vis-à-vis US trends as in Fernandez Kranz (2006). Consequently, the evolution of wage inequality in a wider European context is still rather an unknown puzzle, especially if one focuses on its determinants.

The aim of this paper is to fill in the gap concerning empirical analysis of skilled-unskilled wage gap and returns to education in a large sample of EU countries, encompassing both former EU-15 economies and selected (due to data availability) NMS. As information on tasks performed is not available for such a large sample of countries, wage differentials are considered from the perspective of differences in wages of workers with different educational background. In order to reveal determinants of rising skilled-unskilled wage gap, we consider two main mechanisms: labor substitution across sectors and countries, as well as forces stemming from trade integration in Europe. Throughout the whole analysis we adopt an industry perspective (throughout the text we use words 'sector' and 'industry' as synonyms). We combine recent releases of industrial data, containing complete statistics concerning various skill (education) categories of workers for several European countries with data on trade flows between them. Our final database consists of 12 manufacturing sectors in 20 EU countries across time period 1995-2005.

The rest of the paper is structured as follows: in Section 2, we describe the data and methodology used for the assessment of wage gap patterns. In Section 3 we present some descriptive statistics on the evolution of sector specific wage differentials between employees with different educational background in NMS-5 and EU-15 countries. Section 4 is dedicated to the exploration of the determinants of the wage gap. Using a dataset matching industrial and trade statistics we estimate

1999; Atkinson and Micklewright, 1992; Domanski, 1997; Fereira, 1999; Forster et al. 2005; Holtzner and Leitner, 2008; Milanovic, 1999; Podkaminer, 2003; Sukiassyan, 2007; Wan, 2002).

${ }^{6}$ Bruno et al. (2004) provide evidence on wage dispersion in Poland, Hungary and the Czech Republic; Commander and Kollo (2004) in Hungary, Romania and Russia; Kezdi (2002) in Hungary; Newell and Socha (2007) or Keane and Prasad (2006) in Poland; Sabirianova (2003) in Russia; Skoufias (2003) in Romania. 
a dynamic empirical model, testing to what extent the wage gap between skilled and unskilled workers is linked to (i) labor substitution across domestic and foreign sectors and (ii) changing patterns of trade in Europe. Conclusions follow.

\section{Background for empirical analysis}

\subsection{Related literature}

So far, the empirical literature on skilled-unskilled wage premium has been rather based on individual or firm level data, which allows for the estimation of wage equations at the micro level, but, however, due to limited data availability such analysis is usually characterized by a short time span and/or very restricted country cover (often single countries); in case of NMS constructing a micro panel would be simply impossible. Hence, our analysis is closer to few existing studies, albeit limited in country cover and/or time span, on the wage dynamics in Europe performed at the industry level.

Egger and Stehrer (2003) use the data on real monthly wages in 14 NACE 2-digit manufacturing industries (1993-1999) and analyze the effects of outsourcing and FDI on wage bill between non-manual and manual workers in Czech Republic, Hungary and Poland, finding a positive effect of intermediate goods trade in favour of unskilled workers in these countries, leading to the reduction of skilled-unskilled wage bill ratio. Esposito and Stehrer (2007) use an update of Egger and Stehrer (2003) database (1995-2003) testing sector bias hypothesis, which appears to play an important role in rising relative wage of skilled workers in manufacturing in Hungary and Poland, but not confirmed in the Czech Republic. Onaran and Stockhammer (2008) analyze the case of Czech Republic, Hungary, Poland, Slovakia and Slovenia for the period 2000-2004, using data concerning 14 sectors - they estimate the effects of FDI and trade on real wages (FDI- positive, but small effect, international trade- insignificant) but they do not address the issue of skilled-unskilled wage gap. Bruno et al. (2004) find that in Poland, Hungary and the Czech Republic FDI has not worsened wage inequality by favouring labor demand shifts but it has contributed to raising the skill premium through the role played by multinational firms in the restructuring process during the transition period.

Sector level analysis of trade-labor market interactions across EU countries (both 'old' and 'new' member states) is presented in Lo Turco and Parteka (2011). The authors also draw on EUKLEMS data and estimate an empirical model of sector labor demand for the high- and low- 
skilled, presenting the elasticities of labor demand with respect to domestic and foreign wage conditions. They conclude that in general complementarity between domestic and foreign labor takes place in the enlarged EU, even though in low skill intensive sectors the high skilled in NMS can substitute for employment in EU-15 countries.

Polgár and Wörz (2010) also use sector level data from the same sources as we do (but contrary to Lo Turco and Parteka, 2011 they do not distinguish between wages paid to different skill categories of workers) and analyse the relationship between average wages paid in distinct sectors and openness to trade in 25 EU countries in the period 1995-2005. They find that trade can not be identified as a decisive factor in determining wage levels in manufacturing and services industries. In the last lines of their paper they state (p.150): "Further research should carefully investigate the issue of wage inequality in response to economic integration" and this is exactly what we our paper aims to do. To the best of our knowledge, sector level empirical analysis concerning determinants of skilled/unskilled wage gap in a large set of EU countries, including also NMS, has not been performed so far.

\subsection{Data and panel composition}

In order to obtain information on skill specific wages we draw on recently made available industry specific data from the EUKLEMS Growth and Productivity Accounts database. What is particularly important, apart from providing fully comparable across countries data on output, employment, growth accounting, capital formation and productivity etc., EUKLEMS database contains information which permits us to calculate sector specific hourly wages and, moreover, allows the distinction between wages of different categories of workers (grouped into: high, medium and low skill labor). Skills are defined in EUKLEMS on the base of educational attainment. High skills $(h s)$ correspond to tertiary education, medium skills $(m s)$ - to secondary school completed and low skill $(l s)$ - to workers with primary education only. ${ }^{8}$ Importantly for our purposes, the information on labor compensation and time of work of different skill categories of workers is available both for EU-15 and selected NMS (namely: Poland, Hungary, Czech Republic, Slovak

\footnotetext{
${ }^{7}$ We use release from March 2008. Release November 2009 does not contain information on labor compensation and hours worked of different categories of workers while updata from March 2011 only corrects some values in 2009 revision. See O'Mahony and Timmer (2009) or Timmer et al. (2007) for an overview of the database. Detailed information on sources and methods can be found at: www.euklems.net.

${ }^{8}$ All the series in EUKLEMS database have been created on the base of statistics provided by National Statistical Institutes (NSIs), but basic data has been harmonized in order to ensure cross country and cross industry comparability. Since data by labor types (according to the skill level) are not part of standard statistics reported by NSIs, EUKLEMS uses survey data as background sources (See Timmer et al., 2007 for the details).
} 
Republic and Slovenia, from now on denoted as NMS-5).

Consequently, using variables from EUKLEMS we first calculate sector specific wages per hour of different categories of workers:

$$
w_{i j t}^{k}=\frac{L a b_{i j t}^{k} * L A B_{i j t}}{h_{i j t}^{k} * H_{i j t}}, \vee k=\{h s, m s, l s\}
$$

where, $i$ denotes sector, $j$ - country and $t$ - time; $L A B$ is the value of total labor compensation in a given sector, $H$ denotes the number of total hours worked by persons engaged in the same sector, $L a b^{k}$ is the share of labor compensation of a given $k$ category of workers (high, medium and low skilled) within a sector in total labor compensation, while $h^{k}$ is the share of hours worked by $k$ category of workers expressed as a share of total hours worked in that sector. So obtained wages are then used to calculate wage ratios between workers of different educational skill levels.

Originally, for some EU countries nominal variables (like $L A B$ ) are expressed in national currencies, thus we use bilateral exchange rates and $\mathrm{HICP}^{9}$ (both from Eurostat) to report all wages into constant terms $(2005=100)$ euro. In the end, for each country we obtain a set of sectoral wages (per hour worked) by skill category.

We are interested in the wage gap between skilled (highly educated) and unskilled (less educated) workers, thus for the purpose of our study we aggregate data on skills present in EUKLEMS and deal with two categories: skilled (denoted in our analysis as $S$ ) and unskilled (denoted in our analysis as $U S$ ). In the benchmark analysis we distinguish between workers with and without university education, so that $S=h s$ and $U S=m s+l s$. Consequently, we measure skilled to unskilled wage gap (wg) as:

$$
w g_{i j t}=\frac{w_{i j t}^{S}}{w_{i j t}^{U S}} ; S=h s, U S=m s+l s
$$

where, as before, $i$ denotes sector, $j$ - country and $t$ - time; while $w$ is wage of a given category of workers per hour computed as shown in (1).

All the other industrial statistics used in the empirical model (e.g. employment data used to calculate relative domestic and foreign labor supply or sectoral value added) come also from EUKLEMS.

In order to be able to link wage ratios with trade patterns, we use trade data from

\footnotetext{
${ }^{9}$ Harmonized Index of Consumer Prices.
} 
UNComtrade (retrieved through WITS $^{10}$ ). Originally our trade statistics (value of exports and imports, separately) follow SITC rev.3, 5 digit classification, but we reclassify them in order to have a perfect match with sector level data on wages. ${ }^{11}$ We consider exports and imports in a given sector separately, and express them with respect to value added (VA) of the sector (obtaining trade penetration ratios). Importantly, we compute two alternative groups of indicators of sectoral trade intensity. We consider separately trade of all goods and, in order to assess separately the importance of outsourcing practises, trade in intermediate goods. In order to individuate intermediate goods being the subject of outsourcing practices, we use the list of intermediate products from Molnar et al. (2007, pp. 69-70) and, as suggested by these authors, we treat intermediate goods' imports intensity as a proxy of outsourcing. ${ }^{12}$ Trade statistics originally expressed in current USD were transformed into euro (in which VA is expressed) with current exchange rates from the Eurostat. In order to account for possible heterogeneous effects of trade with distinct countries, we separately take into account trade exchange with the following partners' groups (starting from the most general view on trade - with the whole world): WLD, EU25, EU15, NMS. ${ }^{13}$

In the end, our panel is composed of wage, labor and trade statistics for 20 countries $^{14}$ (Table A1 in the Appendix) and 12 manufacturing sectors (Table A2 in the Appendix) over the period 1995-2005. Note that the selection of countries is not arbitrary but it is due to limited availability of the data ${ }^{15}$ while the final composition of sectors was guided by the necessity to obtain the match between labor and trade statistics.

\footnotetext{
${ }^{10}$ World Integrated Trade Solutions.

${ }^{11}$ Correspondence codes for aggregate codes (3 digit) of trade data and are presented in Table A3 in the Appendix.

${ }^{12}$ Alternative measures of outsourcing are based on input-output tables, unfortunately unavailable for the whole sample of our countries, thus we have to rely on trade based measures of the international outsourcing.

${ }^{13}$ Due to data availability as NMS we consider ten New Member states that joined the EU in 2004. EU25=NMS(10)+EU15. We draw on bilateral trade flows (retrieved at 5 digit level and reclassified in order to correspond with the industrial classification adopted throughout our analysis) between each country and its partners, then aggregating them into flows coming from alternative partners' groups. Observations where reporter=partner have been excluded.

${ }^{14}$ Due to unavailable separate statistics for Belgium and Luxembourg in selected years, we aggregate all series for these countries and treat them jointly $(\mathrm{BLX}=\mathrm{BEL}+\mathrm{LUX})$.

${ }^{15}$ In particular, statistics on labor compensation and time of work of high, medium and low skill workers - needed for the calculation of skill specific wages - are available only for $5 \mathrm{New}$ Member States that we cover in our study. For the remaining NMS EUKLEMS does not provide such data.
} 


\section{Evidence on the evolution of wage inequality in the EU (1995-2005)}

Levels of skilled-unskilled wage gap (returns to education) in European countries are considerable. Table 1 reports the values of wage ratios defined in (2) in various manufacturing sectors for the first and the last year for which we have the information needed for their calculation (1995 and 2005), along with the percentage change between these years. Averages for the groups of countries are weighted by the sector size.

We can see that wage differentials between highly educated and less educated workers are rather persistent and their change in time is rather slow. Treating all countries jointly as EU-20 group, relative wage of highly educated workers with respect to those with less than university education in 2005 ranged between 1.86 in 'Manufacturing nec; recycling' and 2.11 in 'Food,beverages and tobacco'. Between 1995 and $2005 \frac{w^{S}}{w^{U S}}$ rose in three EU-20 sectors: 'Wood and products of wood and cork' (but by only 0.29\%) 'Electrical and optical equipment' (by 4.6\%) and 'Transport equipment' (by 3.6\%).

When we split the sample of countries into former EU-15 and New Member States, in general, looking at the year 2005 levels of wage gap in almost all cases are higher in NMS-5 than in EU-15. On average wages paid to high skilled workers with tertiary education in NMS-5 manufacturing in 2005 were 2.33 times higher than hourly wage of those with lower educational levels. In EU-15 wages offered to high skilled workers in manufacturing were higher by $85 \%$ with respect to wages of less educated labor force.

If we consider the evolution of wage differentials through time, on average it rose only in 2 out of 12 manufacturing sectors in EU-15 and in 9 out of 12 sectors in NMS-5. Also looking at average evolution of skilled-unskilled wage ratio in the whole manufacturing, we can see that the salaries of low educated workers (with primary or medium education only) with respect to wages offered to labor force with university education diminished in New Member States. The opposite took place in EU-15 economies.

In EU-15 countries, skilled-unskilled wage ratio rose only in rather advanced sectors: 'Electrical and optical equipment' and 'Transport equipment'. At the same time in New Member States skilled-unskilled wage gap diminished only in traditional sectors: 'Food,beverages and tobacco', 'Textiles, leather and footwear', and 'Manufacturing nec; recycling'. 
Table 1.Skilled-unskilled hourly wage ratio (returns to education) in manufacturing sectors in EU, by sector, 1995 and 2005

\begin{tabular}{|c|c|c|c|c|c|c|c|c|c|}
\hline \multirow{2}{*}{ sector } & \multicolumn{9}{|l|}{$\frac{w^{S}}{w^{U S}}$} \\
\hline & \multicolumn{3}{|c|}{ EU-20 } & \multicolumn{3}{|c|}{ NMS-5 } & \multicolumn{3}{|c|}{ EU-15 } \\
\hline Food, beverages and tobacco & 2.24 & 2.11 & -5.84 & 2.47 & 2.40 & -3.1 & 2.18 & 2.04 & -6.30 \\
\hline Textiles, leather and footwear & 2.11 & 1.98 & -6.34 & 2.49 & 2.42 & -3.2 & 1.97 & 1.84 & -6.67 \\
\hline Wood and products of wood and cork & 1.97 & 1.98 & 0.29 & 2.18 & 2.24 & 2.8 & 1.91 & 1.88 & -1.49 \\
\hline Chemicals and chemical products & 1.93 & 1.91 & -0.92 & 2.20 & 2.29 & 4.0 & 1.87 & 1.85 & -1.47 \\
\hline Rubber and plastics products & 1.94 & 1.91 & -1.33 & 2.16 & 2.23 & 3.2 & 1.90 & 1.83 & -3.45 \\
\hline Other non-metallic mineral products & 1.94 & 1.91 & -1.27 & 2.14 & 2.22 & 3.8 & 1.89 & 1.84 & -2.54 \\
\hline Basic metals and fabricated metal products & 1.93 & 1.87 & -2.75 & 2.23 & 2.29 & 2.7 & 1.86 & 1.79 & -3.96 \\
\hline Machinery, n.e.c. & 1.99 & 1.94 & -2.56 & 2.33 & 2.39 & 2.6 & 1.91 & 1.86 & -2.65 \\
\hline Electrical and optical equipment & 1.91 & 2.00 & 4.62 & 2.36 & 2.45 & 3.6 & 1.83 & 1.88 & 2.95 \\
\hline Transport equipment & 1.86 & 1.92 & 3.56 & 2.25 & 2.39 & 6.0 & 1.79 & 1.83 & 2.62 \\
\hline Manufacturing nec; recycling & 1.93 & 1.87 & -3.03 & 2.47 & 2.37 & -4.0 & 1.81 & 1.74 & -4.18 \\
\hline
\end{tabular}

Note: Educational groups: S=hs (workers with university education), US=ms+ls (workers with less than university education); EU-20, EU-15 and NMS-5 values are

weighted averages within groups of countries (by hours worked in each sector).

Source: own elaboration with EUKLEMS data. 
Hence, the general observation is that levels of skilled-unskilled wage ratios in the analyzed period were higher New Member States than in EU-15 countries and, on top of that, wage differences rose mainly in manufacturing sectors in NMS.

As far as cross-country differences are concerned, in Figure 1 we show the average (weighted by sectors' size) values of skilled-unskilled wage ratios in separate countries in the 2005. Levels of skilled-unskilled wage gaps were particularly high in such countries as: Hungary (where in 2005 workers with university education employed in manufacturing were paid almost three times more than less educated employees), Czech Republic, Portugal and Slovenia.

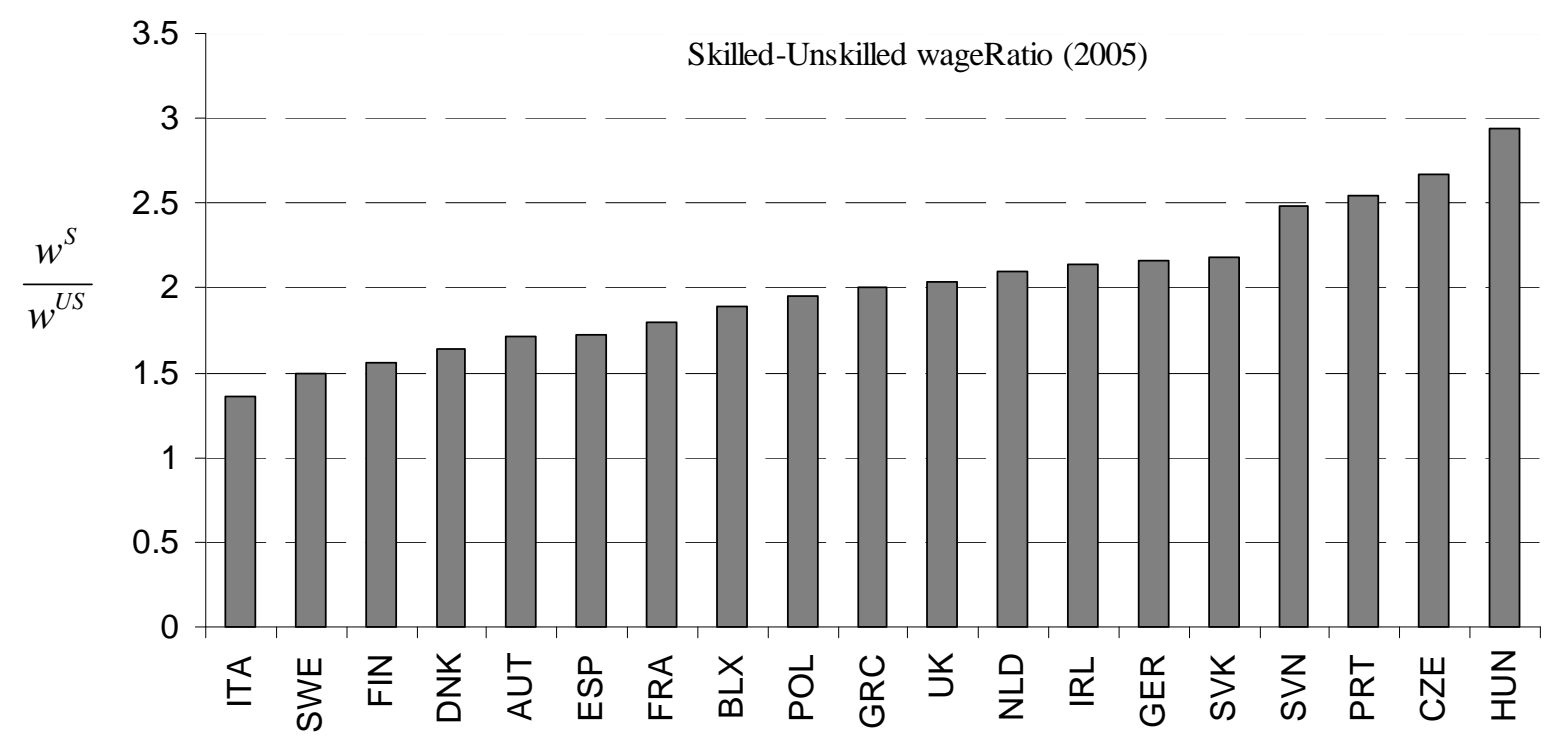

Figure 1. Levels of skilled-unskilled hourly wage gap (returns to education) in manufacturing sectors in EU, by country (2005)

Note: Educational groups: $\mathrm{S}=\mathrm{hs}$ (workers with university education), US=ms + ls (workers with less than university education); values for separate countries are weighted averages (by hours worked in each sector).

Source: own elaboration with EUKLEMS data.

\section{Determinants of skilled-unskilled wage gap}

\subsection{Derivation of the empirical model}

The feature of this paper is rather empirical, but in before presenting the empirical model to be estimated, we first present a simple theoretical framework for the analysis of skilledunskilled wage gap. As a basis we shall use the supply and demand framework presented in Fernandez Kranz (2006) in which relative demand for skills changes because of skill-biased technological change (SBTC) and, additionally, supply and employment conditions affect relative 
skill demand. Let's consider the production function where, apart from capital, skilled $(S)$ and unskilled (US) labor serve as inputs to produce output $Y$ :

$Y_{t}=F\left(K_{t}, \phi_{U S, t} L_{U S, t}, \phi_{S, t} L_{S, t}\right)$

where $K$ denotes capital; $L_{U S}$ and $L_{S}$ represent stocks of unskilled and skilled labor, respectively.

SBTC takes place if $\frac{\dot{\phi_{S}}}{\phi_{S}}>\frac{\dot{\phi}_{U S}}{\phi_{U S}}$ (the growth rate of $\phi_{S}$ is bigger than growth rate of $\phi_{U S}$ ). First order conditions with respect to the input ratios result in the following wage equations (if constant returns to scale are assumed):

$$
\begin{aligned}
& w_{S, t}=F_{1}\left(\frac{\phi_{U S, t} L_{U S, t}}{K_{t}}, \frac{\phi_{S, t} L_{S, t}}{K_{t}}, 1\right) \\
& w_{U S, t}=F_{2}\left(\frac{\phi_{U S, t} L_{U S, t}}{K_{t}}, \frac{\phi_{S, t} L_{S, t}}{K_{t}}, 1\right)
\end{aligned}
$$

where $w_{S}$ and $w_{U S}$ denote wage of skilled and unskilled labor, respectively.

Log-linearization of eq. (4a) and eq. (4b) gives the following representation of wage equations:

$$
\begin{aligned}
& \ln \left(w_{S, t}\right)=\alpha_{0}+\alpha_{1} \ln \left(\frac{\phi_{U S, t} L_{U S, t}}{K_{t}}\right)+\alpha_{2} \ln \left(\frac{\phi_{S, t} L_{S, t}}{K_{t}}\right)+\ln \phi_{S, t} \\
& \ln \left(w_{U S, t}\right)=\beta_{0}+\beta_{1} \ln \left(\frac{\phi_{U S, t} L_{U S, t}}{K_{t}}\right)+\beta_{2} \ln \left(\frac{\phi_{S, t} L_{S, t}}{K_{t}}\right)+\ln \phi_{U S, t}
\end{aligned}
$$

By subtracting eq. (5b) from eq. (5a) we obtain relative (skilled-unskilled) wage equation:

$$
\begin{aligned}
& \ln \left(\frac{w_{S, t}}{w_{U S, t}}\right)=\alpha_{0}+\beta_{0}+\left(1+\alpha_{1}-\beta_{2}\right) \ln \phi_{S, t}-\left(1+\beta_{1}-\alpha_{2}\right) \ln \phi_{U S, t}+ \\
& +\left(\beta_{1}+\beta_{2}-\alpha_{1}-\alpha_{2}\right) \ln \left(\frac{K_{t}}{L_{S, t}}\right)+\left(\beta_{1}-\alpha_{2}\right) \ln \left(\frac{L_{S, t}}{L_{U S, t}}\right)
\end{aligned}
$$

in which wage gap evolution depends on: (i) changes in SBTC components ( $\phi_{S}$ and $\left.\phi_{U S}\right)$; (ii) changes in capital stock if capital-skill complementarity takes place (assuming $\beta_{1}+\beta_{2}-\alpha_{1}-\alpha_{2}>0$ ); (iii) changes in relative (skilled-unskilled) employment which reflects the movement along the demand curve. The first two components reflect the shifts of the demand curve.

Grouping demand-shifting SBTC and capital-skill complementarity components into a joint term $X$ and assuming $\beta_{1}-\alpha_{2}=-\frac{1}{\sigma}$ (with $\sigma$ being the elasticity of substitution between 
skilled and unskilled labor), we reach the following simplified relative (skilled-unskilled) wage equation:

$$
\ln \left(\frac{w_{S, t}}{w_{U S, t}}\right)=\varphi_{0}+X t-\frac{1}{\sigma} \ln \left(\frac{L_{S, t}}{L_{U S, t}}\right)
$$

The form of our empirical sector-level specification draws on theoretical eq.(7) but is limited by the availability of the data (we dispose of information on wages of skilled and unskilled workers in 12 manufacturing sectors - see Section 2.2). Term $X$ is not directly observable and we address this limit by the specific formulation of the estimable model. In particular, in order to capture relative demand and relative supply factors, we use the information on demand for and availability of skilled and unskilled labor force at the level of sectors. Given considerable degree of European labor markets integration, we use the information on relative (skilled to unskilled) labor both in the home country and abroad. In particular, we estimate the following sector-level empirical model with a natural logarithm of skilled-unskilled wage ratio (returns to education) as dependent variable:

$$
\begin{aligned}
& \ln \left(\frac{w_{S}}{w_{U S}}\right)_{i, j, t}=\alpha+\beta \ln \left(\frac{w_{S}}{w_{U S}}\right)_{i, j, t-1}+\lambda_{1} \ln \left(\frac{L d_{S}}{L d_{U S}}\right)_{i, j, t}+\lambda_{2} \ln \left(\frac{L d_{S}}{L d_{U S}}\right)_{-i, j, t}+\delta_{1} \ln \left(\frac{L f_{S}}{L f_{U S}}\right)_{i,-j, t} \\
& +\delta_{2} \ln \left(\frac{L f_{S}}{L f_{U S}}\right)_{-i,-j, t}+\chi \ln u_{j, t}+D_{t}+D_{i j}+\varepsilon_{i j t}
\end{aligned}
$$

where $i=(1, \ldots, 12) \quad$ refers to sectors, $j=(1, . ., 20)$ to countries and $t=(1995, \ldots, 2005)$ to time period; $-i$ denotes sectors other than $i$ and, similarly, $-j$ signifies countries other than domestic country $j ; S$ and US indicate skilled (highly educated) and unskilled (less educated) workers, respectively; $w$ is hourly wage; $L d$ - domestic labor, $L f$ - foreign labor (see below), $u$ unemployment rate.

We adopt a dynamic panel setting in which current skilled-unskilled wage gap is linked, as a persistent phenomenon, with levels of inequality from the previous period. We allow for convergence-type mechanism (if wage gap diminishes in sectors in which it was already high then $\beta$ coefficient is expected to be lower than unity). The lack of the direct information on sector level relative productivity of skilled and unskilled workers may present a limitation of the model, which we address by the inclusion of lagged relative wage levels of the two categories of workers - in the light of economic theory it should be correlated with their lagged relative productivity levels, thus $\beta$ coefficient will partially capture productivity effects.

Among explanatory variables in the first instance we include a proxy of relative (skilled to 
unskilled) domestic labor demand in a sector under question: $\left(\frac{L d_{S}}{L d_{U S}}\right)_{i, j}$. This measure also reflects relative (with respect to less educated workers) bargaining power of skilled workers employed in the domestic sector. We expect that major demand for skilled workers, with respect to the unskilled, will shift up wage differences between them. In order to account for the mobility of labor force across domestic sectors (skills are defined here on the base of educational level and not tasks performed, so e.g. at least some educated workers can switch between sectors), we also consider relative availability of labor force actively present on domestic labor market and currently employed in sectors other than $i:\left(\frac{L d_{S}}{L d_{U S}}\right)_{-i, j}$.

Next, given that EU countries are characterised by a substantial degree of labor markets integration, we consider possible substitution of domestic workers employed in sector $i$ by labor force employed in the same sector in foreign countries. Hence, we take into account relative (skilled to unskilled) foreign labor size in the same sector: $\left(\frac{L f_{S}}{L f_{U S}}\right)_{i,-j}$. Additionally, by including the information on relative availability of skilled to unskilled foreign labor currently employed in other sectors, $\left(\frac{L f_{S}}{L f_{U S}}\right)_{-i,-j}$, we also consider the possibility of indirect (e.g. resulting from the movement across foreign sectors) substitution of domestic workers with foreign ones.

To complete the information on labor force availability, we also include information on the unemployment rate (at the level of countries since we do not have sector-specific unemployment data), $u_{j}$ Part of the potential labor supply can be represented by those currently without a job and in case of low unemployment, wage ratios can be determined by relative scarsity of labor force available on the market. On top of that, labor market conditions (e.g. high unemployment in the country) can also influence the bargaining power of workers currently employed and, consequently, the ability of skilled workers to call for relatively higher wages.

Next, we enrich the empirical model (8a) by the inclusion of trade factors:

$$
\begin{aligned}
& \ln \left(\frac{w_{S}}{w_{U S}}\right)_{i, j, t}=\alpha+\beta \ln \left(\frac{w_{S}}{w_{U S}}\right)_{i, j, t-1}+\lambda_{1} \ln \left(\frac{L d_{S}}{L d_{U S}}\right)_{i, j, t}+\lambda_{2} \ln \left(\frac{L d_{S}}{L d_{U S}}\right)_{-i, j, t}+\delta_{1} \ln \left(\frac{L f_{S}}{L f_{U S}}\right)_{i,-j, t} \\
& +\delta_{2} \ln \left(\frac{L f_{S}}{L f_{U S}}\right)_{-i,-j, t}+\chi \ln u_{j, t}+\gamma\left(\Delta \ln \frac{\operatorname{trade} e^{p}}{V A}\right)_{i, j, t}+D_{t}+D_{i j}+\varepsilon_{i j t}
\end{aligned}
$$

where trade denotes the trade flow and $V A$ - value added and $p$ refers to a specific group of trade 
partners, so that $\frac{\operatorname{trade}^{p}}{V A}$ reflects trade openness of every manufacturing sector under examination (value of trade flows concerning goods from the sector with respect to its value added). While estimating model (8b) we consider trade $=\{$ exp, imp, expInterm, impInterm $\}$ in order to take into account heterogeneous effects according to the direction of flow and the typology of goods traded (all goods: exp, imp, or intermediate goods only: expInterm, impInterm). Additionally, $p=\{W L D, E U 25, E U 15, N M S\}$ denotes alternative partners' group, so that we are able to verify if skilled-unskilled wage gap is affected differently by goods exchange with various typologies of partners. Note that we consider separately exports and imports of intermediate goods only: expInterm and impInterm - these two variables reflect the importance of trade in parts and components; in particular the imports of intermediates can be considered as a proxy of outsourcing practices. If skilled-unskilled wage gap is determined by the intensification of trade then we should obtain positive and significant estimates of parameter $\gamma$.

Finally, the estimated models take into account time invariant country-sector specificities $\left(D_{i j}\right)$ and time effects $\left(D_{t}\right)$ allowing for business cycle effects. All the variables enter the model in natural logs, thus the estimated coefficients can be interpreted as elasticities while variables expressed in first differences (trade variables) approximately reflect their rates of growth.

To sum up the empirical strategy: we consider the interplay between two main forces in shaping skilled-unskilled wage differentials: labor market developments (demand for and availability of skilled and unskilled labor force, both at home and abroad) and trade intensification in Europe.

\subsection{Results}

\subsubsection{Initial remarks}

We estimate equation (3) using observations for 20 countries, 12 sectors and 11 years (1995-2005) with panel identification given by country-sector pairs, thus the number of observations is relatively large and the number of time periods is relatively small with respect to the number of groups. As for the estimation strategy, the choice of the estimator is driven by the fact that wage inequality tends to be a persistent process and, additionally, some regressors can be endogenous. The introduction of the lagged dependent variable makes the fixed-effect estimator inconsistent, thus we use system GMM estimator (Blundell and Bond, 1998; Roodman, 2009) which applies system of difference and levels equations and is particularly suitable for persistent series (our case). 
In order to avoid problems linked to the instrument proliferation (Roodman, 2008) we use limited number of lags of variables used as instruments, assuring the drop in the number of instruments with respect to the number of groups (we report both the number of groups and the number of instruments in the tables with estimation results). We report two-step results with finite sample correction of Windmeijer (2005). All the explanatory variables except dummies and unemployment rate are assumed to be predetermined but not strictly exogenous and are instrumented.

Potential collinearity between explanatory variables was formally checked. There results to be no need to omit any labor market variable from the model because of collinearity. However, we do not include contemporarily in the regressions alternative trade openness measures, as they tend to be correlated, but consider them one by one in separate models.

Results based on sector level data can be driven by outliers, thus we used algorithm proposed by Billor et al. (2000), identifying multiple outliers in multivariate data. We adopted 10th percentile of the chi-squared distribution to be used as a threshold to separate outliers eventually excluded from the sample - from non outliers. Summary statistics of the variables used in the estimations are presented in Table A4 in the Appendix.

\subsubsection{Estimation results}

In the following tables we show the results of the estimation of model (8a), (8b) obtained with skilled/unskilled wage gap measure measuring the ratio of wages of workers with university education to salaries paid to less educated workers.

All of the the estimated models include lagged dependent variable, a set of labor market statistics and a set of dummies (see eq.3). In order to assure easy legibility of the results, we separately present estimations referring to different types of trade. In Table 2 we present the set of results obtained with measures of export penetration ratios (value of exports to various groups of partners with respect to sector's value added). Table 3 contains analogical results, but with import penetration ratios (again, we consider separately imports from different partners' groups). Next, we show the results referring to the estimates obtained with trade penetration measures concerning the exchange of intermediate goods only - ratio of their exports to VA (Table 4) and ratio of their imports to VA (Table 5). P-values of autocorrelation test $\operatorname{AR}(2)$ have expected values which proves correct formulation of the dynamic model. Number of instruments never exceeds the number of groups and p-values associated with Hansen (1982) J statistics testing overidentifying restrictions (under the null hypothesis that the instruments are valid) confirm, at standard levels of significance, that adopted model structure is suitable. 
Table 2. Estimation results (model (8a), (8b)) obtained with export penetration measures (all goods)

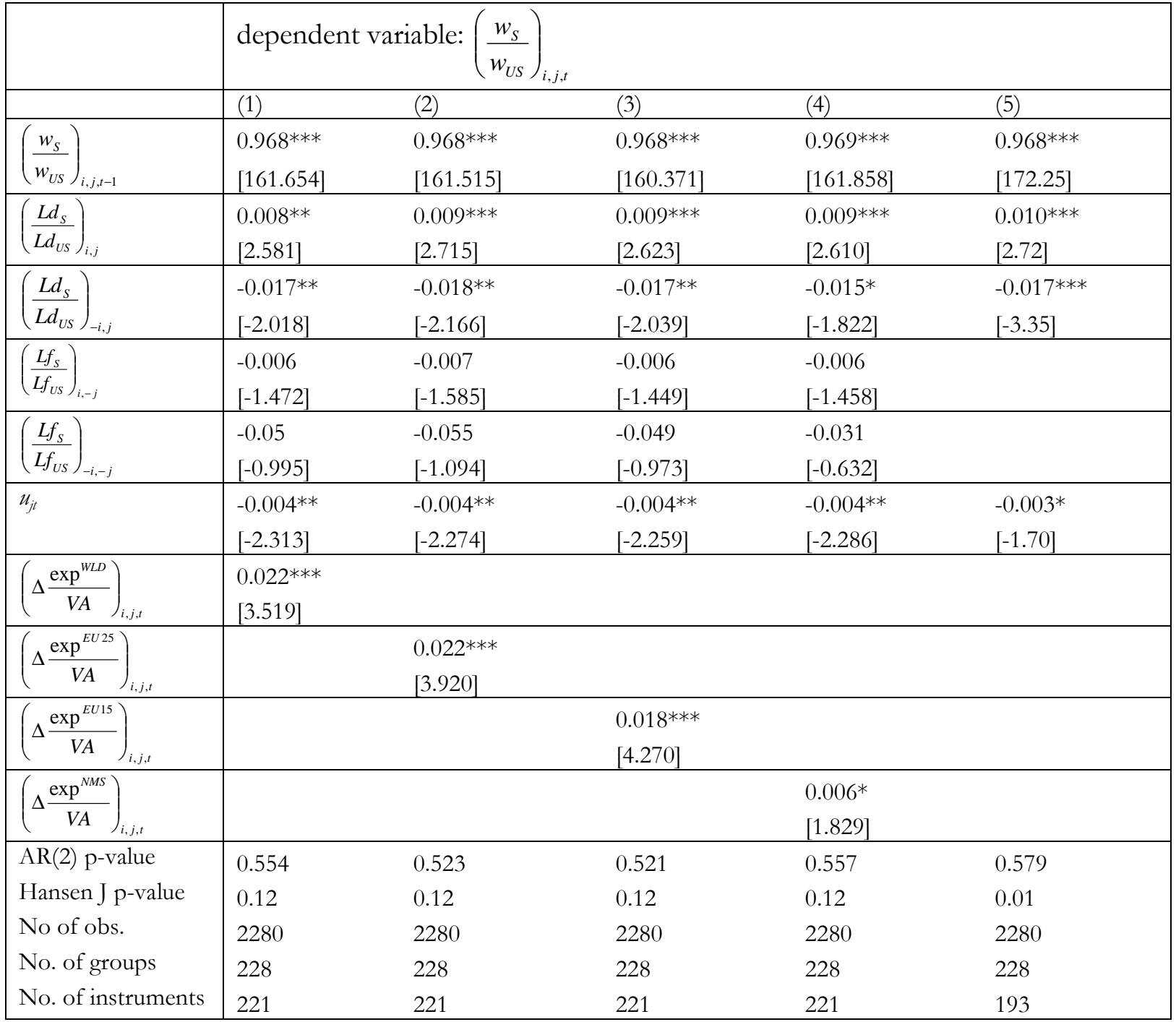

Note:; Results are two-step System GMM with the Windmeijer (2005) correction; $i$ refers to sectors, $j$ to countries, $t$ to time period. Educational groups: $\mathrm{S}=\mathrm{hs}$ (workers with university education), $\mathrm{US}=\mathrm{ms}+\mathrm{ls}$ (workers with less than university education);

t-statistics in brackets, *significant at $10 \%$; **significant at $5 \%$; ***significant at $1 \%$. Variables in natural logs. Estimations performed without outliers $\left(10^{\text {th }}\right.$ percentile $)$ in the sense of Billor et al. (2000). Time dummies included not reported.

Source: own elaboration 
Table 3. Estimation results (model (8a), (8b)) obtained with import penetration measures (all goods)

\begin{tabular}{|c|c|c|c|c|c|}
\hline & dependen & le: $\left(\frac{w_{S}}{w_{U S}}\right)_{i}$ & & & \\
\hline & $(1)$ & $(2)$ & (3) & (4) & (5) \\
\hline$\left(\frac{w_{S}}{w_{U S}}\right)_{i, j, t-1}$ & $\begin{array}{l}0.969 * * * \\
{[166.715]}\end{array}$ & $\begin{array}{l}0.968 * * * \\
{[166.274]}\end{array}$ & $\begin{array}{l}0.968^{* * *} \\
{[163.495]}\end{array}$ & $\begin{array}{l}0.969 * * * \\
{[160.788]}\end{array}$ & $\begin{array}{l}0.968^{* * *} \\
{[172.25]}\end{array}$ \\
\hline$\left(\frac{L d_{s}}{L d_{U S}}\right)_{i, j}$ & $\begin{array}{l}0.008 * * \\
{[2.596]}\end{array}$ & $\begin{array}{l}0.009 * * * \\
{[2.674]}\end{array}$ & $\begin{array}{l}0.009 * * * \\
{[2.660]}\end{array}$ & $\begin{array}{l}0.008^{* *} \\
{[2.351]}\end{array}$ & $\begin{array}{l}0.010^{* * *} \\
{[2.72]}\end{array}$ \\
\hline$\left(\frac{L d_{S}}{L d_{U S}}\right)_{-i, j}$ & $\begin{array}{l}-0.015^{*} \\
{[-1.863]}\end{array}$ & $\begin{array}{l}-0.016^{* *} \\
{[-1.996]}\end{array}$ & $\begin{array}{l}-0.016 * * \\
{[-2.046]}\end{array}$ & $\begin{array}{l}-0.015^{*} \\
{[-1.802]}\end{array}$ & $\begin{array}{l}-0.017 * * * \\
{[-3.35]}\end{array}$ \\
\hline$\left(\frac{L f_{s}}{L f_{U S}}\right)_{i,-j}$ & $\begin{array}{l}-0.006 \\
{[-1.311]}\end{array}$ & $\begin{array}{l}-0.006 \\
{[-1.431]}\end{array}$ & $\begin{array}{l}-0.006 \\
{[-1.395]}\end{array}$ & $\begin{array}{l}-0.006 \\
{[-1.286]}\end{array}$ & \\
\hline$\left(\frac{L f_{S}}{L f_{U S}}\right)_{-i,-j}$ & $\begin{array}{l}-0.032 \\
{[-0.662]}\end{array}$ & $\begin{array}{l}-0.036 \\
{[-0.757]}\end{array}$ & $\begin{array}{l}-0.038 \\
{[-0.787]}\end{array}$ & $\begin{array}{l}-0.035 \\
{[-0.702]}\end{array}$ & \\
\hline$u_{j t}$ & $\begin{array}{l}-0.004 * * \\
{[-2.291]}\end{array}$ & $\begin{array}{l}-0.003 * * \\
{[-2.183]}\end{array}$ & $\begin{array}{l}-0.003 * * \\
{[-2.109]}\end{array}$ & $\begin{array}{l}-0.003 * * \\
{[-2.117]}\end{array}$ & $\begin{array}{l}-0.003^{*} \\
{[-1.70]}\end{array}$ \\
\hline$\left(\Delta \frac{i m p^{W L D}}{V A}\right)_{i, j, t}$ & $\begin{array}{l}0.01 \\
{[1.554]}\end{array}$ & & & & \\
\hline$\left(\Delta \frac{i m p^{E U 25}}{V A}\right)_{i, j, t}$ & & $\begin{array}{l}0.013 * \\
{[1.961]}\end{array}$ & & & \\
\hline$\left(\Delta \frac{i m p^{E U 15}}{V A}\right)_{i, j, t}$ & & & $\begin{array}{l}0.012 * * \\
{[2.033]}\end{array}$ & & \\
\hline$\left(\Delta \frac{i m p^{N M S}}{V A}\right)_{i, j, t}$ & & & & $\begin{array}{l}-0.003 \\
{[-0.994]}\end{array}$ & \\
\hline $\mathrm{AR}(2) \mathrm{p}$-value & 0.571 & 0.569 & 0.565 & 0.569 & 0.579 \\
\hline Hansen J p-value & 0.12 & 0.12 & 0.12 & 0.12 & 0.01 \\
\hline No of obs. & 2280 & 2280 & 2280 & 2280 & 2280 \\
\hline No. of groups & 228 & 228 & 228 & 228 & 228 \\
\hline No. of instruments & 221 & 221 & 221 & 221 & 193 \\
\hline
\end{tabular}

Note:; Results are two-step System GMM with the Windmeijer (2005) correction; $i$ refers to sectors, $j$ to countries, $t$ to time period. Educational groups: $\mathrm{S}=\mathrm{hs}$ (workers with university education), $\mathrm{US}=\mathrm{ms}+\mathrm{ls}$ (workers with less than university education).

t-statistics in brackets, *significant at $10 \%$; **significant at $5 \%$; ***significant at $1 \%$. Variables in natural logs. Estimations performed without outliers $\left(10^{\text {th }}\right.$ percentile) in the sense of Billor et al. (2000). Time dummies included not reported.

Source: own elaboration 
Table 4. Estimation results (model (8a), (8b)) obtained with intermediate goods' exports penetration measures

\begin{tabular}{|c|c|c|c|c|c|}
\hline & depende & iable: $(n$ & & & \\
\hline & $(1)$ & $(2)$ & (3) & (4) & $(5)$ \\
\hline$\left(w_{S}\right)$ & $0.969 * * *$ & $0.969 * * *$ & $0.969 * * *$ & $0.972^{* * *}$ & $0.968^{* * *}$ \\
\hline$\left(\overline{w_{U S}}\right)_{i, j, t-1}$ & {$[170.838]$} & {$[169.876]$} & [167.972] & [163.902] & [172.25] \\
\hline$\left(L d_{S}\right)$ & $0.008^{* *}$ & $0.008^{* *}$ & $0.008^{* *}$ & $0.009 * * *$ & $0.010^{* * *}$ \\
\hline$\left(\overline{L d_{U S}}\right)_{i, j}$ & {$[2.456]$} & {$[2.562]$} & [2.449] & {$[2.632]$} & {$[2.72]$} \\
\hline$\left.L d_{S}\right)$ & $-0.015^{*}$ & $-0.016 * *$ & $-0.015^{*}$ & $-0.014 *$ & $-0.017 * * *$ \\
\hline$\left(\overline{L d_{U S}}\right)_{-i, j}$ & {$[-1.917]$} & {$[-2.023]$} & {$[-1.910]$} & [-1.729] & {$[-3.35]$} \\
\hline$\left(\underline{L f_{S}}\right)$ & -0.006 & -0.006 & -0.006 & -0.006 & \\
\hline$\left(\overline{L f_{U S}}\right)_{i,-j}$ & {$[-1.320]$} & {$[-1.461]$} & {$[-1.360]$} & {$[-1.413]$} & \\
\hline$\left(L f_{S}\right)$ & -0.042 & -0.045 & -0.039 & -0.044 & \\
\hline$\left(\overline{L f_{U S}}\right)_{-i,-j}$ & {$[-0.844]$} & [-0.922] & {$[-0.789]$} & {$[-0.895]$} & \\
\hline$u_{j t}$ & $-0.004 * *$ & $-0.004 * *$ & $-0.004 * *$ & $-0.003 * *$ & $-0.003^{*}$ \\
\hline & {$[-2.334]$} & [-2.289] & {$[-2.264]$} & {$[-2.144]$} & {$[-1.70]$} \\
\hline$\left(\Delta \exp ^{\operatorname{exterm}}{ }^{W L D}\right)$ & $0.015^{* * *}$ & & & & \\
\hline$\left(\Delta \frac{\nabla A}{V A}\right)_{i, j, t}$ & {$[2.828]$} & & & & \\
\hline$\left(\Delta \exp ^{\operatorname{exterm}}{ }^{E U 25}\right)$ & & $0.014 * * *$ & & & \\
\hline$(\Delta-V A)_{i, j, t}$ & & {$[3.427]$} & & & \\
\hline$\left(\Delta \exp ^{\operatorname{exterm}}{ }^{E U 15}\right)$ & & & $0.010^{* * *}$ & & \\
\hline$\left(\begin{array}{lll}\Delta & V A\end{array}\right)_{i, j, t}$ & & & {$[3.148]$} & & \\
\hline$\left(\Delta \frac{\exp \text { Interm }^{N M S}}{}\right)$ & & & & 0.001 & \\
\hline$(\Delta-V A)_{i, j, t}$ & & & & {$[0.417]$} & \\
\hline AR(2) p-value & 0.563 & 0.536 & 0.531 & 0.572 & 0.579 \\
\hline Hansen J p-value & 0.12 & 0.12 & 0.12 & 0.12 & 0.01 \\
\hline No of obs. & 2280 & 2280 & 2280 & 2267 & 2280 \\
\hline No. of groups & 228 & 228 & 228 & 228 & 228 \\
\hline No. of instruments & 221 & 221 & 221 & 221 & 193 \\
\hline
\end{tabular}

Note:; Results are two-step System GMM with the Windmeijer (2005) correction; $i$ refers to sectors, $j$ to countries, $t$ to time period. Educational groups: $\mathrm{S}=\mathrm{hs}$ (workers with university education), $\mathrm{US}=\mathrm{ms}+\mathrm{ls}$ (workers with less than university education);

t-statistics in brackets, *significant at $10 \%$; **significant at $5 \%$; ***significant at $1 \%$. Variables in natural logs. Estimations performed without outliers (10 $0^{\text {th }}$ percentile) in the sense of Billor et al. (2000). Time dummies included not reported.

Source: own elaboration 
Table 5. Estimation results (model (8a), (8b)) obtained with intermediate goods' imports penetration measures

\begin{tabular}{|c|c|c|c|c|c|}
\hline & \multicolumn{5}{|c|}{ dependent variable: $\left(\frac{w_{S}}{w_{U S}}\right)$} \\
\hline & (1) & (2) & (3) & (4) & (5) \\
\hline$\left(w_{S}\right)$ & $0.969 * * *$ & $0.969 * * *$ & $0.969 * * *$ & $0.970^{* * *}$ & $0.968^{* * *}$ \\
\hline$\left(w_{U S}\right)_{i, j, t-1}$ & {$[167.234]$} & [166.834] & [164.017] & [143.297] & {$[172.25]$} \\
\hline$\left(L d_{S}\right)$ & $0.008^{* *}$ & $0.008^{* *}$ & $0.008^{* *}$ & $0.009 * *$ & $0.010^{* * *}$ \\
\hline$\left(\overline{L d_{U S}}\right)_{i, j}$ & {$[2.521]$} & {$[2.492]$} & [2.492] & [2.509] & {$[2.72]$} \\
\hline$\left.L d_{S}\right)$ & $-0.015^{*}$ & $-0.015^{*}$ & $-0.015^{*}$ & $-0.016^{*}$ & $-0.017 * * *$ \\
\hline$\left(\overline{L d_{U S}}\right)_{-i, j}$ & {$[-1.878]$} & {$[-1.915]$} & {$[-1.865]$} & {$[-1.722]$} & {$[-3.35]$} \\
\hline$\left(\underline{L f_{S}}\right)$ & -0.006 & -0.006 & -0.005 & -0.007 & \\
\hline$\left(\overline{L f_{U S}}\right)_{i,-j}$ & {$[-1.357]$} & {$[-1.372]$} & {$[-1.277]$} & {$[-1.494]$} & \\
\hline$\left(L f_{S}\right)$ & -0.038 & -0.037 & -0.033 & -0.057 & \\
\hline$\left(\overline{L f_{U S}}\right)_{-i,-j}$ & {$[-0.772]$} & {$[-0.761]$} & {$[-0.666]$} & {$[-1.090]$} & \\
\hline$u_{j t}$ & $-0.003^{* *}$ & $-0.003^{* *}$ & $-0.003 * *$ & $-0.003^{* *}$ & $-0.003^{*}$ \\
\hline & {$[-2.146]$} & {$[-2.088]$} & {$[-2.137]$} & {$[-2.045]$} & {$[-1.70]$} \\
\hline$\left(\Delta\right.$ impInterm $\left.^{W L D}\right)$ & $0.012^{* *}$ & & & & \\
\hline$V A)_{i, j, t}$ & {$[2.037]$} & & & & \\
\hline$\left(\Delta\right.$ impInterm $\left.^{E U 25}\right)$ & & $0.010^{* *}$ & & & \\
\hline$\left(\Delta \frac{\Delta A}{V A}\right)_{i, j, t}$ & & & & & \\
\hline$\left(\Delta\right.$ impInterm $\left.^{E U 15}\right)$ & & & $0.010^{* *}$ & & \\
\hline$(\Delta-V A)_{i, j, t}$ & & & {$[2.084]$} & & \\
\hline$\left(\Delta\right.$ impInterm $\left.^{N M S}\right)$ & & & & -0.002 & \\
\hline 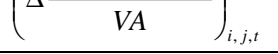 & & & & [-0.939] & \\
\hline AR(2) p-value & 0.569 & 0.569 & 0.562 & 0.588 & 0.579 \\
\hline Hansen J p-value & 0.12 & 0.12 & 0.12 & 0.12 & 0.01 \\
\hline No of obs. & 2280 & 2280 & 2280 & 2259 & 2280 \\
\hline No. of groups & 228 & 228 & 228 & 228 & 228 \\
\hline No. of instruments & 221 & 221 & 221 & 221 & 193 \\
\hline
\end{tabular}

Note:; Results are two-step System GMM with the Windmeijer (2005) correction; $i$ refers to sectors, $j$ to countries, $t$ to time period. Educational groups: $\mathrm{S}=\mathrm{hs}$ (workers with university education), $\mathrm{US}=\mathrm{ms}+\mathrm{ls}$ (workers with less than university education);

t-statistics in brackets, *significant at $10 \%$; **significant at 5\%; ***significant at $1 \%$. Variables in natural logs. Estimations performed without outliers $\left(10^{\text {th }}\right.$ percentile) in the sense of Billor et al. (2000). Time dummies included not reported.

Source: own elaboration 
In all specifications, as expected, parameter associated with lagged value of skilled/unskilled wage gap results to be significant and $|\beta|<1$. Skilled/unskilled wage ratio results to be a highly persistent feature of the labour markets in the analysed European countries. It is in line with descriptive statistics shown in Table 1. Note that due to the presence of dependent variable's data series highly dependent on its realisations in the past, estimated values of coefficients associated with other explanatory variables are small in value.

As far as domestic labor market statistics are concerned, positive and statistically significant parameter in front of $\left(\frac{L d_{S}}{L d_{U S}}\right)_{i, j}$ denotes that major domestic demand for highly educated workers, with respect to those with lower educational background, shifts up wage differences between them. Hence, a rise in skilled/unskilled wage ratio in manufacturing sectors can be linked to changes in employment structure in the same domestic sectors in favour of highly educated labor force. Such a result can be interpreted in line with the arguments of skill-biased technological change hypothesis. When we consider labor composition in other domestic sectors, the opposite result takes place: $\left(\frac{L d_{s}}{L d_{U S}}\right)_{-i, j}$ describing skill structure of workers in domestic sectors other than $i$, is among significant and negative determinants of skilled-unskilled wage gap in sector $i$. Consequently, allowing for the mobility of workers across domestic sectors, there results to be some degree of substitution between domestic labor force. Relative major availability of educated workers actively present on national labor market weakens the bargaining power of these workers with respect to the unskilled. Moreover, independently on the specification and choice of trade variables included in the model, overall domestic unemployment rate always results to be among negative determinants of skilled/unskilled wage gap. All these results hold no matter what other variables are included into the model.

Contrastingly, we do not find similar effects when we consider labor structure in foreign countries. Neither $\left(\frac{L f_{s}}{L f_{U S}}\right)_{i,-j}$ nor $\left(\frac{L f_{S}}{L f_{U S}}\right)_{-i,-j}$, describing respectively the availability of skilled to unskilled labor abroad - both in the same sector and in other sectors, results to be among statistically significant determinants of skilled-unskilled wage gap in domestic manufacturing sectors. Consequently, we do not find a support for a direct threat, at least in terms of influencing wage differentials, that foreign labor can pose to the domestic one.

Turning to trade measures, skilled-unskilled wage gap is affected positively by a rise in export penetration ratio, independently on the destination of goods (Table 2). Imports exert similar effect, but only when we consider imports of manufacturing goods from EU treated as a whole or from EU15 countries. However, interestingly, major trade penetration of a sector with 
respect to imports from NMS is not statistically linked to wage inequality at home (Table 3). Looking at trade in intermediates only (Table 4 and Table 5), both intensification in their imports and exports is in general positively related to skilled-unskilled wage gap. However, again, there is no significant evidence on wage effects of intermediate goods trade with NMS.

Hence, the role of trade in shaping wage differentials among different skill groups of workers in the European countries is more complicated than it is commonly perceived. In particular, when we correct for labor market characteristics, intensification of trade and outsourcing practises with New Member States does not result to determine wage inequality between workers of different educational levels.

\subsection{Extensions and robustness checks}

In order to check the robustness of our results, we have considered several modifications in the estimated empirical model.

First of all, we have consider a change in econometric strategy. We have repeated all the estimations with one step system GMM estimator, obtaining no significant alteration of the results and conclusions drawn (results available upon request).

Secondly, in order to verify if adopted division of workers into skilled and unskilled group matters for the conclusions drawn, we considered alternative grouping, distinguishing between two border categories of workers (thus workers with tertiary education and those with primary education only), so that $S=h s$ and $U S=l s$. An alternative wage gap is calculated as:

$$
w g_{-} b i s_{i j t}=\frac{w_{i j t}^{S}}{w_{i j t}^{U S}} ; S=h s, U S=l s
$$

where $i$ denotes sector, $j$ - country and $t$ - time, while $w$ is wage of a given category of workers per hour as in (3). Results of the estimations are reported in Tables Rob 1.1-1.4 in the Appendix. Skilled/unskilled wage gap still results to be a highly persistent phenomena and key findings concerning the rise in relative (here: to wages offered to workers with primary education only) skilled wage along with a rise in relative domestic demand for skilled workers hold. Similarly, as in benchmark estimations, a rise in unemployment rate weakens the bargaining power of workers and affects negatively wage differentials between high and low educated workers. Then, in a modified framework, relative availability of labor employed currently in other domestic sectors is negatively linked to skilled/unskilled wage differentials (a signal of possible substitution of labor across domestic sectors), but the significance of this variable depends on the type of trade considered (it looses significance if the role of imports is accounted for ). Moreover, 
in contrast with benchmark results, when we consider wage gap between border categories of educational levels, there are signs of substitution between foreign and domestic labor within the

same sectors: foreign relative labor, $\left(\frac{L f_{s}}{L f_{U S}}\right)_{i,-j}$ results to be a negative and statistically significant determinant of skilled/unskilled wage gap in the same sector at home. At the same time, trade seems to loose importance. Putting these two results together, we can conclude that wage differences between workers with university education with respect to those with primary education only are less prone to trade forces, but more sensitive to relative demand for and availability of these two groups of workers in domestic and foreign labor markets.

\section{Conclusions}

Main aim of this paper was to analyze the evolution of wage gap between skilled and unskilled workers (returns to education) in Europe in the period of rapid trade integration between EU-15 countries and Central and Eastern Europe, undergoing the process of economic transformation. Our results draw on sector level analysis (12 manufacturing sectors) based on combined labor and trade data for 20 European countries (EU-15 and NMS-5) within the years 1995-2005. We test simultaneously the effects of labor market developments (considering separately domestic and foreign labor markets) and trade effects on wage differentials. So far empirical literature has not provided such a broad view on the topic of wage differentials between different skill (educational) groups of workers in a wide European context, encompassing both former EU-15 economies and New Member States.

The data permit us to trace the changes in the evolution of relative wages between alternative groups of workers, classified according to the educational levels (unfortunately, for such a vast group of European countries information on tasks performed is unavailable). On top of that, we are able to confront patterns of skilled-unskilled wage gap (returns to education) in EU-15 countries and in selected New Member States. Emerging evidence is interesting.

Wage differentials across employees with different educational background are considerable. On average in EU-15 countries in 2005 workers with university education employed in manufacturing earned (by hour) $85 \%$ more than those with at most secondary education; in NMS-5: 2.33 times more. The general evidence emerging from sector-level data is that levels of skilled/unskilled wage ratios in the analyzed period were higher in New Member States than in EU-15 countries and, on top of that, wage differences rose mainly in NMS. Moreover, high skilled/unskilled wage differentials result to be highly persistent, changing very 
slowly through time.

We have estimated dynamic panel data model in order to find the determinants of wage inequality in our sample of countries. We have considered separately the effects driven by relative (skilled to unskilled) demand for and supply of labor in domestic and foreign manufacturing sectors. Additionally, we analysed the role played by a rise in their trade openness. In order to provide as complete view as possible, we have analysed separately effects of trade with different groups of partners (e.g. distinguishing between goods exchange with former EU-15 and NMS), also making a distinction between trade in all goods and trade in intermediate parts and components only.

Skilled/unskilled wage ratios (between workers with university education and lower) result to be linked mainly to domestic labor conditions and, to a lower extent, to trade patterns in Europe. Shift of employment structure in favour of skilled workers is a positive determinant of the wage gap in the same sector at home. Such a result can be interpreted in line with skill biased technological change hypothesis. On the contrary, greater general relative availability of skilled workers on domestic labor market, weakens their bargaining power and tends to be associated with lower skilled-unskilled wage differentials. Hence, in the context of wage gaps between employees characterized by different educational levels, some mobility of labor across sectors within the same country can play a role. It will be hardly imaginable if skills were defined on the base of tasks performed.

Due to significant degree of labor markets in the enlarged European Union, we have also considered cross-country effects of labor supply on wage inequality patterns. We first considered differences in wages paid to employees with university education with respect to salaries of workers with primary and/or secondary education. We found no statistically significant effects of foreign labor markets on the evolution of domestic wage differentials in manufacturing. However, the situation changes if we take into account differences in salaries of the most educated workers with respect to those with primary education only. In such context, foreign labor availability affects negatively wage differentials at home - there are signs of substitution between foreign and domestic labor within the same manufacturing sectors when workers with intermediate education are excluded from the sample.

As far as the role of trade forces in concerned, in general sectors with major changes in penetration ratios are characterized by higher wage differentials between workers with and without university education. However, our data does not support a view that trade with NMS can be blamed for a rise in wage inequality in European manufacturing. It is an important result, questioning the common view on wage inequality driven by trade with less developed countries. 
Given difficulties with gathering comparable sector-level data for several EU countries, our analysis focused on wage differences between workers with various educational levels. Further research is certainly needed to uncover determinants of wage inequality between workers performing different types of tasks. From the points of view of data availability, such an exercise is particularly demanding, but it could undoubtedly shed some new light on wage effects of the division of tasks across the enlarged EU.

\section{Acknowledgments}

The author gratefully acknowledges financial support from CERGE-EI (10th GDN RRCGlobal Development Network Regional Research Competition). 


\section{References}

Acemoglu D. (2002). Technical change, inequality and the labor market. Journal of Economic Literature, Vol.XL:7-72.

Aghion P. and S. Commander (1999). On the dynamics of inequality in the transition. Economics of Transition, 7: 275-289.

Atkinson A. and J. Micklewright (1992). Economic transformation in Eastern Europe and the distribution of income. Cambridge University Press, London.

Attanasio O., P.K. Goldberg and N. Pavcnik (2004). Trade reforms and wage inequality in Colombia. Journal of Development Economics, 74(2): 331-366.

Arellano M. and Bover (1995). Another look at the instrumental variable estimation of errorcomponents model. Journal of Econometrics, 68: 29-51.

Autor D., L. Katz and A. Krueger (1998). Computing inequality: have computers changed the labor market. Quarterly Journal of Economics, 113: 1169-1215.

Autor D., L. Katz, M. Kearney (2008). Trends in U.S. Wage Inequality: Revising the Revisionists. Review of Economics and Statistics, 90(2), 300-323.

Baldone S., F. Sdogati and L. Tajoli (2001). Patterns and determinants of international fragmentation of production: evidence from outward processing trade between EU and Central Eastern European Countries. Review of World Economics/Weltwirtschaftliches Archiv 137(1): 80-104.

Bartel A. and N. Sicherman (1999). Technological change and wages: an interindustry analysis. Journal of Political Economy, 107(2): 285-325.

Berman E., J. Bound and Z. Griliches (1994). Changes in the Demand for Skilled Labor within U.S. Manufacturing: Evidence from the Annual Survey of Manufacturers. The Quarterly Journal of Economics, 109(2): 367- 397.

Billor, N., A. S. Hadi, and P. F. Velleman. (2000). BACON: Blocked adaptive computationally efficient outlier nominators. Computational Statistics \& Data Analysis, 34: 279-298.

Boeri T. and K. Terrell (2002). Institutional Determinants of Labor Reallocation in Transition. The Journal of Economic Perspectives, 16(1): 51-76.

Burtless G. (1995). International Trade and the Rise in Earnings Inequality. Journal of Economic Literature, 33(2): 800-816.

Bruno G., Crinò R. and A.M. Falzoni (2004). Foreign Direct Investment, wage inequality and skilled labor demand in EU Accession Countries. Centro Studi Luca d'Agliano Development Studies Working Papers No. 188.

Chamarbagwala R. (2006). Economic liberalisation and wage inequality in India. World Development, 34(12): 1997-2015.

Commander S. and J. Kollo (2004). The changing demand for skills: evidence from the transition. IZA Discussion Paper No. 1073

Di Nardo J. and D. Card (2002). Skill biased technological change and rising wage inequality: some problems and puzzles. Journal of Labor Economics, 20(4): 733-783.

Davis E.R. (1996). Trade liberalization and income distribution. NBER Working Paper No. w5693.

Domanski H. (1997). Distribution of incomes in Eastern Europe. International Journal of Comparative Sociology, 38: 249-270. 
Dulleck U., N.Foster, R.Stehrer and J. Wörz (2005). Dimensions of quality upgrading. Evidence from CEECs. Economics of Transition, 13(1): 51-76.

Egger H. and P. Egger (2005). The determinants of EU processing trade. The World Economy 28(2): 147-168.

Egger P. and R. Stehrer (2003). International outsourcing and the skill specific wage bill in Eastern Europe. The World Economy 26(1): 61-72.

Esposito P., Stehrer R. (2007). The Sector Bias of Skill-biased Technical Change and the Rising Skill Premium in Transition Economies, WIIW Working Papers 43, The Vienna Institute for International Economic Studies.

EUKLEMS Database (March 2008). University of Groningen and University of Birmingham; downloadable at wnw.enklems.net

Feenstra R. and G. Hanson (1996). Foreign Investment, Outsourcing and Relative Wages. [in:] Feenstra R., G.Grossman and D.Irwin (Eds.), The Political Economy of Trade Policy: Paper in Honour of Jagdish Bhagwati. MIT Press, 89-127.

Feenstra R. and G. Hanson (2001). Global production sharing and rising inequality: a survey of trade and wages. NBER Working Paper 8372.

Fernandez Kranz D. (2008). Why has wage inequality increased more in the USA than in Europe? An empirical investigation of the demand and supply of skill. Applied Economics, 38: 771788.

Ferreira F. (1999). Economic transition and the distribution of income and wealth. Economics of Transition, 7: 377-410.

Förster M., D. Jesuit and T. Smeeding (2005). Regional poverty and income inequality in Central and Eastern Europe: evidence from the Luxembourg income study [in:] Spatial Inequality and Development, ed. R Kanbur, A.J. Venables, Chapter 13, Oxford University Press, New York.

Green F., Felstead A., Gallie D. (2003). Computers and the changing skill-intensity of jobs. Applied Economics, 35: 1651-1676.

Grossman G.M. and E. Rossi-Hansberg (2008). Trading tasks: a simple theory of offshoring. American Economic Review, 98(5): 1978-1997

Hansen, L. (1982). Large sample properties of generalized method of moments estimators. Econometrica, 50(3): 1029-54.

Haskel J. and M. Slaughter (2001). Trade, Technology and UK wage inequality. The Economic Journal, 111: 163-187.

Heyns B. (2005). Emerging inequalities in Central and Eastern Europe. Annual Review of Sociology, 31: 163-197.

Holtzner M. and S. Leitner (2008). Economic Inequality in Central, East and Southeastern Europe, in: Intervention. Journal of Economics, 5(1):

Kaminski B. and F. Ng (2005). Production disintegration and integration of Central Europe into global markets. International Review of Economics and Finance, 14: 377-390.

Katz L.F. and K. Murphy (1992). Changes in Relative Wages, 1963-1987: Supply and Demand Factors. The Quarterly Journal of Economics, 107(1): 35-78.

Katz L. and D. Autor (1999). Changes in the wage structure and earnings inequality. [in:] Orley, Ashenfelter and Card (eds.) The Handbook of labor Economics Vol.III, Elsevier, Amsterdam.

Keane M.P. and E.S. Prasad (2006). Changes in the structure of earnings during the Polish 
transition. Journal of Development Economics, 80: 389-427.

Keller W. (2002). Trade and the transmission of technology. Journal of Economic Growth 7: 5-24.

Kezdi G. (2002). Two phases of labor market transition in Hungary: inter-sectoral reallocation and skill-biased technological change. Budapest Working Papers on the Labor Market 2002/3.

Kornai J. (2006). The great transformation of Central Eastern Europe. Economics of Transition, 14 (2): 207-244.

Leamer E. (1992). Wage effects of a US-Mexican Free Trade Agreement. NBER Working Paper No. 3991.

Leamer E. (1996). Wage inequality from international competition and technological change: theory and country experience. American Economic Review Papers and Proceedings, 86(2): 309-314.

Lo Turco A. and Parteka A. (2011). The demand for skills and labour costs in partner countries Evidence from the enlarged EU. Economics of Transition, 19(3): 611-637. DOI: 10.1111/j.14680351.2011.00412.x

Machin (1996). Wage inequality in the UK. Oxford Review of Economic Policy, 12(1): 47-64.

Manasse P., L. Stanca and A. Turrini (2004). Wage premia and skill upgrading in Italy: why didn't the hound bark? Labour Economics, 11: 59-83.

Milanovic B. (1999). Explaining the increase in inequality during transition. Economics of Transition, 7: 299-341.

Molnar, M., N. Pain and D. Taglioni (2007). The Internationalisation of Production, International Outsourcing and Employment in the OECD, OECD Economics Department Working Papers, No. 561, OECD Publishing. doi:10.1787/167350640103

Newell A. and M.W. Socha (2007). The Polish wage inequality explosion. The Economics of Transition, 15: 733-758.

Onaran Ö. and E. Stockhammer (2008). The effect of FDI and foreign trade on wages in the Central and Eastern European Countries in the post-transition era: a sectoral analysis for the manufacturing industry. Structural Change and Economic Dynamics, 19: 66-80.

O'Mahony M. and M.P. Timmer (2009). Output, input and productivity measures at the industry level: the EUKLEMS database. Economic Journal, 119(538): F374-F403.

Podkaminer L. (2003). A note on the evolution of inequality in Poland, 1992-99. Cambridge Journal of Economics, 27: 755-768.

Polgár E.K. and J. Wörz (2010). No risk and some fun? Trade and wages in the enlarged European Union. Empirica, 37: 127-163.

Robertson R. (2004). Relative prices and wage inequality: evidence from Mexico. Journal of International Economics, 64(2): 387-409.

Roodman (2009). How to do xtabond2: An introduction to difference and system GMM in Stata, Stata Journal, StataCorp LP, 9(1): 86-136.

Rutkowski J. (1997). Low wage employment in transitional economies of central and eastern Europe. MOCT-MOST, 7: 105-130.

Sabirianova Peter K. (2003). Skill-biased transition: the role of markets, institutions and technological change. IZA Discussion Paper No. 893.

Skoufias E. (2003). The structure of wages during the economic transition in Romania. Economic Systems, 27: 345-366. 
Sukiassyan G. (2007). Inequality and growth: what does the transition economy data say. Journal of Comparative Economics, 35: 35-56.

Timmer M.P., O'Mahony M. and van Ark. B. (2007). Growth and Productivity Accounts from EUKLEMS: an Overview. National Institute Economic Review, 200(1): 64-78.

Wan G.H. (2002). Income inequality and growth in transition economies. World Institute for Development Economics Research Discussion Paper No. 104.

United Nations Statistics Division (2008). Commodity Trade Statistics Database (UNComtrade), available through World Integrated Trade Solutions (wnw.wits.worldbank.org/witsweb)

Welsch H. (2004). Skill intensity and export growth in West German manufacturing. Applied Economics Letters, 11: 513-515.

Wood A. (1991). How much does trade with the south affects workers in the north? World Bank Research Observer 6: 19-36.

Wood A. (1994). North-South trade, employment and inequality: changing fortunes in a skill-driven world. Clarendon Press, Oxford.

Wood A. (1995). How Trade Hurt Unskilled Workers. The Journal of Economic Perspectives, 9(3): 5780 .

Zaghini A. (2005). Evolution of trade patterns in the New EU member states. Economics of Transition 13(4): 629-658. 


\section{Appendix}

Table A1. List of countries

\begin{tabular}{|c|c|}
\hline \multicolumn{2}{|l|}{ EU-20 } \\
\hline EU-15 & NMS-5 \\
\hline AUT Austria & CZE Czech Republic \\
\hline BLX Belgium and Luxembourg* & HUN Hungary \\
\hline DNK Denmark & POL Poland \\
\hline ESP Spain & SVK Slovak Republic \\
\hline FIN Finland & SVN Slovenia \\
\hline FRA France & \\
\hline GER Germany & \\
\hline GRC Greece & \\
\hline IRL Ireland & \\
\hline ITA Italy & \\
\hline NLD Netherlands & \\
\hline PRT Portugal & \\
\hline SWE Sweden & \\
\hline UK United Kingdom & \\
\hline
\end{tabular}

Note: $*$ treated jointly (BLX=BEL+LUX).

Table A2. List of sectors

\begin{tabular}{|l|l|}
\hline 1 & Food,beverages and tobacco \\
\hline 2 & Textiles,leather and footwear \\
\hline 3 & Wood and products of wood and cork \\
\hline 4 & Pulp,paper,printing and publishing \\
\hline 5 & Chemicals and chemical products \\
\hline 6 & Rubber and plastics products \\
\hline 7 & Other non-metallic mineral products \\
\hline 8 & Basic metals and fabricated metal products \\
\hline 9 & Machinery, n.e.c. \\
\hline 10 & Electrical and optical equipment \\
\hline 11 & Transport equipment \\
\hline 12 & Manufacturing nec; recycling \\
\hline
\end{tabular}


Table A3.Correspondence table between trade and labor sectors

\begin{tabular}{|c|c|c|c|}
\hline \multicolumn{2}{|r|}{ UNComtrade sector (SITC) } & \multicolumn{2}{|r|}{ EUKLEMS sector (NACE) } \\
\hline code & name & code & name \\
\hline 154 & Vegetable and animal oils and fats & \multirow[t]{10}{*}{$15 \mathrm{t} 16$} & Food,beverages and tobacco \\
\hline 152 & Fish and fish products & & Food,beverages and tobacco \\
\hline 158 & Other food products & & Food,beverages and tobacco \\
\hline 159 & Beverages & & Food,beverages and tobacco \\
\hline 157 & Prepared animal feeds & & Food,beverages and tobacco \\
\hline 155 & Dairy products; ice cream & & Food,beverages and tobacco \\
\hline 151 & Meat products & & Food,beverages and tobacco \\
\hline 156 & Grain mill products and starches & & Food,beverages and tobacco \\
\hline 153 & Fruits and vegetables & & Food,beverages and tobacco \\
\hline 160 & Tobacco products & & Food,beverages and tobacco \\
\hline 171 & Textile fibres & \multirow[t]{12}{*}{$17 \mathrm{t} 19$} & Textiles,leather and footwear \\
\hline 176 & Knitted and crocheted fabrics & & Textiles,leather and footwear \\
\hline 177 & Knitted and crocheted articles & & Textiles,leather and footwear \\
\hline 174 & Made-up textile articles & & Textiles, leather and footwear \\
\hline 172 & Textile weaving & & Textiles, leather and footwear \\
\hline 175 & Other textiles & & Textiles,leather and footwear \\
\hline 181 & Leather clothes & & Textiles,leather and footwear \\
\hline 183 & Dressing and dyeing of fur; article & & Textiles,leather and footwear \\
\hline 182 & Other wearing apparel and accessories & & Textiles, leather and footwear \\
\hline 191 & Tanning and dressing of leather & & Textiles, leather and footwear \\
\hline 192 & Luggage, handbags, saddlery and har & & Textiles,leather and footwear \\
\hline 193 & Footwear & & Textiles,leather and footwear \\
\hline 205 & Other products of wood; articles of wood and cork & \multirow[t]{5}{*}{20} & Wood and products of wood and cork \\
\hline 201 & Sawmilling, planing and impregnation & & Wood and products of wood and cork \\
\hline 204 & Wooden containers & & Wood and products of wood and cork \\
\hline 202 & Panels and boards of wood & & Wood and products of wood and cork \\
\hline 203 & Builders' carpentry and joinery & & Wood and products of wood and cork \\
\hline 212 & Articles of paper and paperboard & \multirow[t]{4}{*}{$21 \mathrm{t} 22$} & Pulp,paper,printing and publishing \\
\hline 211 & Pulp, paper and paperboard & & Pulp,paper,printing and publishing \\
\hline 222 & Printing & & Pulp,paper,printing and publishing \\
\hline 221 & Publishing & & Pulp,paper,printing and publishing \\
\hline 243 & Paints, coatings, printing ink & \multirow[t]{7}{*}{24} & Chemicals and chemical products \\
\hline 241 & Basic chemicals & & Chemicals and chemical products \\
\hline 246 & Other chemical products & & Chemicals and chemical products \\
\hline 244 & Pharmaceuticals & & Chemicals and chemical products \\
\hline 247 & Man-made fibres & & Chemicals and chemical products \\
\hline 245 & Detergents, cleaning and polishing, & & Chemicals and chemical products \\
\hline 242 & Pesticides, other agro-chemical pro & & Chemicals and chemical products \\
\hline 251 & Rubber products & \multirow[t]{2}{*}{25} & Rubber and plastics \\
\hline 252 & Plastic products & & Rubber and plastics \\
\hline 262 & Ceramic goods & \multirow[t]{6}{*}{26} & Other non-metallic mineral products \\
\hline 261 & Glass and glass products & & Other non-metallic mineral products \\
\hline 267 & Cutting, shaping, finishing of stones & & Other non-metallic mineral products \\
\hline 266 & Articles of concret, plaster and ce & & Other non-metallic mineral products \\
\hline 264 & Bricks, tiles and construction products & & Other non-metallic mineral products \\
\hline 265 & Cement, lime and plaster & & Other non-metallic mineral products \\
\hline
\end{tabular}




\begin{tabular}{|c|c|c|c|}
\hline 268 & Other non-metallic mineral products & & Other non-metallic mineral products \\
\hline 263 & Ceramic tiles and flags & & Other non-metallic mineral products \\
\hline 274 & Basic precious and non-ferrous metal products & \multirow[t]{9}{*}{$27 \mathrm{t} 28$} & Basic metals and fabricated metal products \\
\hline 273 & Other first processing of iron and & & Basic metals and fabricated metal products \\
\hline 272 & Tubes & & Basic metals and fabricated metal products \\
\hline 271 & Basic iron and steel, ferro-alloys & & Basic metals and fabricated metal products \\
\hline 286 & Cutlery, tools and general hardware & & Basic metals and fabricated metal products \\
\hline 282 & Tanks, reservoirs, central heating & & Basic metals and fabricated metal products \\
\hline 283 & Steam generators & & Basic metals and fabricated metal products \\
\hline 281 & Structural metal products & & Basic metals and fabricated metal products \\
\hline 287 & Other fabricated metal products & & Basic metals and fabricated metal products \\
\hline 297 & Domestic appliances n. e. c. & \multirow[t]{7}{*}{29} & Machinery, n.e.c. \\
\hline 292 & Other general purpose machinery & & Machinery, n.e.c. \\
\hline 295 & Other special purpose machinery & & Machinery, n.e.c. \\
\hline 296 & Weapons and ammunition & & Machinery, n.e.c. \\
\hline 294 & Machine-tools & & Machinery, n.e.c. \\
\hline 291 & Machinery for production, use of $\mathrm{m}$ & & Machinery, n.e.c. \\
\hline 293 & Agricultural and forestry machinery & & Machinery, n.e.c. \\
\hline 300 & Office machinery and computers & \multirow[t]{14}{*}{30 t33 } & Electrical and optical equipment \\
\hline 316 & Electrical equipment n. e. c. & & Electrical and optical equipment \\
\hline 312 & Electricity distribution and contro & & Electrical and optical equipment \\
\hline 313 & Isolated wire and cable & & Electrical and optical equipment \\
\hline 314 & Accumulators, primary cells and pri & & Electrical and optical equipment \\
\hline 315 & Lighting equipment and electric lam & & Electrical and optical equipment \\
\hline 311 & Electric motors, generators and tra & & Electrical and optical equipment \\
\hline 322 & TV, and radio transmitters, apparat & & Electrical and optical equipment \\
\hline 323 & $\mathrm{TV}$, radio and recording apparatus & & Electrical and optical equipment \\
\hline 321 & Electronic valves and tubes, other & & Electrical and optical equipment \\
\hline 334 & Optical instruments and photographi & & Electrical and optical equipment \\
\hline 332 & Instruments for measuring, checking & & Electrical and optical equipment \\
\hline 331 & Medical equipment & & Electrical and optical equipment \\
\hline 335 & Watches and clocks & & Electrical and optical equipment \\
\hline 343 & Parts and accessories for motor vehicles & \multirow[t]{8}{*}{$34 \mathrm{t} 35$} & Transport equipment \\
\hline 341 & Motor vehicles & & Transport equipment \\
\hline 342 & Bodies for motor vehicles, trailers & & Transport equipment \\
\hline 354 & Motorcycles and bicycles & & Transport equipment \\
\hline 352 & Railway locomotives and rolling sto & & Transport equipment \\
\hline 355 & Other transport equipment n. e. c. & & Transport equipment \\
\hline 353 & Aircraft and spacecraft & & Transport equipment \\
\hline 351 & Ships and boats & & Transport equipment \\
\hline 365 & Games and toys & \multirow[t]{6}{*}{$36 \mathrm{t} 37$} & Manufacturing nec; recycling \\
\hline 363 & Musical instruments & & Manufacturing nec; recycling \\
\hline 364 & Sports goods & & Manufacturing nec; recycling \\
\hline 366 & Miscellaneous manufacturing n. e. c & & Manufacturing nec; recycling \\
\hline 362 & Jewellery and related articles & & Manufacturing nec; recycling \\
\hline 361 & Furniture & & Manufacturing nec; recycling \\
\hline
\end{tabular}


Table A4. Summary statistics of variables included in empirical model

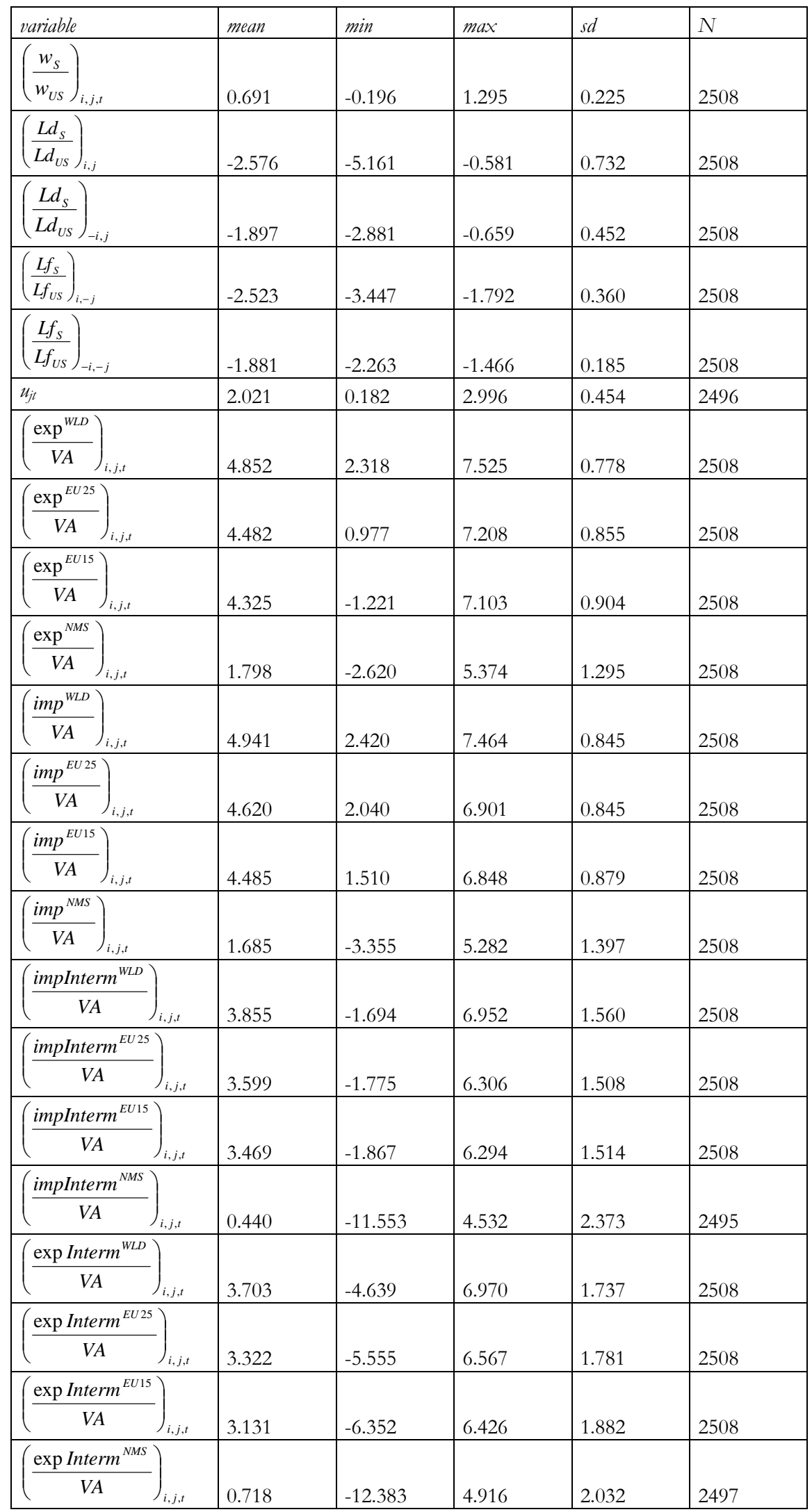


Table Rob1.1 Estimation results (model 8a, 8b) obtained with export penetration measures (all goods)

\begin{tabular}{|c|c|c|c|c|}
\hline & depende & iable: $\left(\frac{w_{S}}{w_{U S}}\right.$ & $=\mathrm{hs}, \mathrm{US}=$ & \\
\hline & $(1)$ & (2) & (3) & (4) \\
\hline$w_{S}$ & $0.983^{* * *}$ & $0.984^{* * *}$ & $0.985^{* * *}$ & $0.983 * * *$ \\
\hline$\left(\overline{w_{U S}}\right)_{i, j, t-1}$ & [190.673] & [187.478] & [187.584] & [179.661] \\
\hline$\left(\underline{L d_{s}}\right)$ & $0.015^{* * *}$ & $0.015^{* * *}$ & $0.015^{* * *}$ & $0.014^{* * *}$ \\
\hline$\left(L d_{U S}\right)_{i, j}$ & [4.825] & {$[5.010]$} & [5.019] & [4.889] \\
\hline$\left(L d_{s}\right)$ & $-0.006^{*}$ & $-0.007 *$ & $-0.006^{*}$ & -0.005 \\
\hline$\left(\overline{L d_{U S}}\right)_{-i, j}$ & {$[-1.788]$} & {$[-1.898]$} & {$[-1.855]$} & {$[-1.367]$} \\
\hline$\left(\frac{L f_{s}}{s}\right)$ & $-0.010^{* * *}$ & $-0.010^{* * *}$ & $-0.010^{* * *}$ & $-0.009 * * *$ \\
\hline$\left(\overline{L f_{U S}}\right)_{i,-j}$ & {$[-2.944]$} & {$[-3.063]$} & {$[-3.031]$} & {$[-2.858]$} \\
\hline$\left(L f_{S}\right)$ & -0.014 & -0.017 & -0.018 & -0.003 \\
\hline$\left(\overline{L f_{U S}}\right)_{-i,-j}$ & {$[-0.536]$} & {$[-0.651]$} & {$[-0.688]$} & {$[-0.129]$} \\
\hline$u_{j t}$ & $-0.007 * *$ & $-0.007^{* *}$ & $-0.007 * *$ & $-0.007 * * *$ \\
\hline & {$[-2.554]$} & {$[-2.581]$} & {$[-2.543]$} & {$[-2.629]$} \\
\hline$\left(\Delta \frac{\exp ^{W L D}}{}\right)$ & $0.013^{*}$ & & & \\
\hline$(\Delta \overline{V A})_{i, j, t}$ & [1.842] & & & \\
\hline$\left(\Delta \Delta \frac{\exp ^{E U 25}}{10}\right)$ & & $0.012^{* *}$ & & \\
\hline$\left(\Delta \frac{\Delta A}{V A}\right)_{i, j, t}$ & & {$[2.018]$} & & \\
\hline$\left(\Delta \exp ^{E U 15}\right)$ & & & $0.011^{* *}$ & \\
\hline$\left(\Delta \frac{\Delta A}{V A}\right)_{i, j, t}$ & & & [2.152] & \\
\hline$\left(\Delta \Delta \frac{\exp ^{N M S}}{)}\right)$ & & & & 0.003 \\
\hline$\left(\Delta \frac{-V A}{V A}\right)_{i, j, t}$ & & & & {$[0.615]$} \\
\hline AR(2) p-value & 0.448 & 0.432 & 0.424 & 0.467 \\
\hline Hansen J p-value & 0.15 & 0.15 & 0.15 & 0.15 \\
\hline No of obs. & 2231 & 2231 & 2231 & 2231 \\
\hline No. of groups & 225 & 225 & 225 & 225 \\
\hline No. of instruments & 221 & 221 & 221 & 221 \\
\hline
\end{tabular}

Note:; Results are two-step System GMM with the Windmeijer (2005) correction; $i$ refers to sectors, $j$ to countries, $t$ to time period. Educational groups: $\mathrm{S}=\mathrm{hs}$ (workers with university education), $\mathrm{US}=\mathrm{ls}$ (workers with primary education only).

t-statistics in brackets, *significant at $10 \%$; **significant at $5 \%$; ***significant at $1 \%$. Variables in natural logs. Estimations performed without outliers (10 th percentile) in the sense of Billor et al. (2000). Time dummies included not reported.

Source: own elaboration 
Table Rob1.2 Estimation results (model 8a,8b) obtained with import penetration measures (all goods)



Note:; Results are two-step System GMM with the Windmeijer (2005) correction;. $i$ refers to sectors, $j$ to countries, $t$ to time period. Educational groups: $\mathrm{S}=\mathrm{hs}$ (workers with university education), $\mathrm{US}=\mathrm{ls}$ (workers with primary education only).

t-statistics in brackets, *significant at $10 \%$; **significant at $5 \%$; ***significant at $1 \%$. Variables in natural logs. Estimations performed without outliers (10 th percentile) in the sense of Billor et al. (2000). Time dummies included not reported.

Source: own elaboration 
Table Rob1.3 Estimation results (model 8a, 8b) obtained with intermediate goods' exports penetration measures

\begin{tabular}{|c|c|c|c|c|}
\hline & depender & ciable: $(n$ & $=\mathrm{hs}, \mathrm{US}=$ & \\
\hline & (1) & (2) & (3) & (4) \\
\hline$\left(w_{S}\right)$ & $0.982^{* * *}$ & $0.983^{* * *}$ & $0.983^{* * *}$ & $0.982 * * *$ \\
\hline$\left(w_{U S}\right)_{i, j, t-1}$ & {$[186.775]$} & [187.349] & {$[189.167]$} & [183.805] \\
\hline$\left(\underline{L d_{S}}\right)$ & $0.015^{* * *}$ & $0.015^{* * *}$ & $0.015^{* * *}$ & $0.015^{* * *}$ \\
\hline$\left(\overline{L d_{U S}}\right)_{i, j}$ & [4.974] & [4.902] & {$[4.877]$} & {$[4.878]$} \\
\hline$\left(L d_{S}\right)$ & $-0.006^{*}$ & $-0.006^{*}$ & $-0.006^{*}$ & -0.005 \\
\hline$\left(L d_{U S}\right)_{-i, j}$ & {$[-1.670]$} & {$[-1.764]$} & {$[-1.741]$} & {$[-1.523]$} \\
\hline$\left(L f_{S}\right)$ & $-0.010^{* * *}$ & $-0.010^{* * *}$ & $-0.010^{* * *}$ & $-0.010^{* * *}$ \\
\hline$\left(\overline{L f_{U S}}\right)_{i,-j}$ & {$[-3.025]$} & {$[-3.076]$} & {$[-2.978]$} & {$[-2.862]$} \\
\hline$\left(L f_{S}\right)$ & -0.008 & -0.01 & -0.009 & -0.008 \\
\hline$\left(\overline{L f_{U S}}\right)_{-i,-j}$ & {$[-0.327]$} & {$[-0.407]$} & {$[-0.349]$} & {$[-0.305]$} \\
\hline$u_{j t}$ & $-0.007 * * *$ & $-0.007 * *$ & $-0.007 * *$ & $-0.007 * *$ \\
\hline & {$[-2.669]$} & {$[-2.595]$} & {$[-2.583]$} & {$[-2.541]$} \\
\hline$\left(\Delta \exp ^{\operatorname{exterm}}{ }^{W L D}\right)$ & $0.009 *$ & & & \\
\hline$(V A)_{i, j, t}$ & {$[1.770]$} & & & \\
\hline$\left(\Delta\right.$ exp Interm $\left.^{E U 25}\right)$ & & 0.007 & & \\
\hline$\left(\Delta \frac{\Delta A}{V A}\right)_{i, j, t}$ & & [1.619] & & \\
\hline$\left(\Lambda \exp ^{\text {Interm }}{ }^{E U 15}\right)$ & & & 0.005 & \\
\hline$(\Delta-V A)_{i, j, t}$ & & & [1.569] & \\
\hline$\left(\Delta \exp\right.$ Interm $\left.^{N M S}\right)$ & & & & 0 \\
\hline$\left(\begin{array}{ll} & V A\end{array}\right)_{i, j, t}$ & & & & [-0.019] \\
\hline AR(2) p-value & 0.461 & 0.445 & 0.443 & 0.473 \\
\hline Hansen J p-value & 0.15 & 0.15 & 0.15 & 0.15 \\
\hline No of obs. & 2231 & 2231 & 2231 & 2218 \\
\hline No. of groups & 225 & 225 & 225 & 225 \\
\hline No. of instruments & 221 & 221 & 221 & 221 \\
\hline
\end{tabular}

Note:; Results are two-step System GMM with the Windmeijer (2005) correction; $i$ refers to sectors, $j$ to countries, $t$ to time period. Educational groups: $\mathrm{S}=\mathrm{hs}$ (workers with university education), $\mathrm{US}=\mathrm{ls}$ (workers with primary education only).

t-statistics in brackets, *significant at $10 \%$; **significant at $5 \%$; ***significant at $1 \%$. Variables in natural logs. Estimations performed without outliers (10 th percentile) in the sense of Billor et al. (2000). Time dummies included not reported.

Source: own elaboration 
Table Rob1.4 Estimation results (model 8a, 8b) obtained with intermediate goods' imports penetration measures

\begin{tabular}{|c|c|c|c|c|}
\hline & depende & riable: $(1$ & $=\mathrm{hs}, \mathrm{US}=$ & \\
\hline & (1) & (2) & (3) & (4) \\
\hline$\left(w_{S}\right)$ & $0.983^{* * *}$ & $0.983^{* * *}$ & $0.982^{* * *}$ & $0.980^{* * *}$ \\
\hline$\left(w_{U S}\right)_{i, j, t-1}$ & [184.954] & [184.794] & {$[185.133]$} & {$[168.234]$} \\
\hline$\left(L d_{S}\right)$ & $0.014^{* * *}$ & $0.015^{* * *}$ & $0.015^{* * *}$ & $0.017 * * *$ \\
\hline$\left(\overline{L d_{U S}}\right)_{i, j}$ & {$[4.660]$} & [4.703] & {$[4.767]$} & {$[5.323]$} \\
\hline$\left.L d_{S}\right)$ & -0.005 & $-0.006^{*}$ & -0.005 & $-0.007 *$ \\
\hline$\left(\overline{L d_{U S}}\right)_{-i, j}$ & {$[-1.584]$} & {$[-1.658]$} & {$[-1.565]$} & {$[-1.945]$} \\
\hline$\left(\underline{L f_{S}}\right)$ & $-0.009 * * *$ & $-0.010^{* * *}$ & $-0.010^{* * *}$ & $-0.011 * * *$ \\
\hline$\left(\overline{L f_{U S}}\right)_{i,-j}$ & {$[-2.801]$} & {$[-2.921]$} & [-2.949] & {$[-3.036]$} \\
\hline$\left(L f_{S}\right)$ & -0.012 & -0.012 & -0.011 & 0.008 \\
\hline$\left(\overline{L f_{U S}}\right)_{-i,-j}$ & {$[-0.461]$} & {$[-0.467]$} & {$[-0.415]$} & {$[0.283]$} \\
\hline$u_{j t}$ & $-0.006^{* *}$ & $-0.007 * *$ & $-0.007 * *$ & $-0.008 * * *$ \\
\hline & {$[-2.392]$} & {$[-2.423]$} & {$[-2.485]$} & {$[-3.059]$} \\
\hline$\left(\Delta\right.$ impInterm $\left.^{W L D}\right)$ & 0.006 & & & \\
\hline$V A)_{i, j, t}$ & {$[0.882]$} & & & \\
\hline$\left(\Delta\right.$ impInterm $\left.^{E U 25}\right)$ & & 0.006 & & \\
\hline$\left(\Delta \frac{\Delta A}{V A}\right)_{i, j, t}$ & & & & \\
\hline$\left(\Delta\right.$ impInterm $\left.^{E U 15}\right)$ & & & 0.006 & \\
\hline$(\Delta-V A)_{i, j, t}$ & & & [1.182] & \\
\hline$\left(\Delta\right.$ impInterm $\left.^{N M S}\right)$ & & & & -0.003 \\
\hline 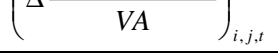 & & & & {$[-1.426]$} \\
\hline AR(2) p-value & 0.479 & 0.472 & 0.461 & 0.486 \\
\hline Hansen J p-value & 0.15 & 0.15 & 0.15 & 0.15 \\
\hline No of obs. & 2231 & 2231 & 2231 & 2210 \\
\hline No. of groups & 225 & 225 & 225 & 225 \\
\hline No. of instruments & 221 & 221 & 221 & 221 \\
\hline
\end{tabular}

Note:; Results are two-step System GMM with the Windmeijer (2005) correction; $i$ refers to sectors, $j$ to countries, $t$ to time period. Educational groups: $\mathrm{S}=\mathrm{hs}$ (workers with university education), $\mathrm{US}=\mathrm{ls}$ (workers with primary education only).

t-statistics in brackets, *significant at $10 \%$; **significant at $5 \%$; ***significant at $1 \%$. Variables in natural logs. Estimations performed without outliers (10 th percentile) in the sense of Billor et al. (2000). Time dummies included not reported.

Source: own elaboration 
Institute for Development

UI. A. Mickiewicza 10 | 81-832 Sopot

e-mail: office@instytut-rozwoju.org

www.instytut-rozwoju.org 